\title{
A Structural Evaluation of Urban Design Guidelines in Turkey and The Performance-Based Approach for Sustainability
}

\author{
Simge Özdal Oktay ${ }^{1}$, Özge Yalçıner Ercoşkun ${ }^{\odot}$ \\ ${ }^{1}$ Post Doctoral Researcher, Institute for Geoinformation, University of Munster, Munster, Germany. (Principal contact for \\ editorial correspondence), Email: soezdalo@uni-muenster.de \\ ${ }^{2}$ Prof. Dr., Faculty of Architecture, Gazi University, Ankara, Turkey. Email: ozgeyal@gazi.edu.tr
}

\begin{abstract} Purpose

Urban design guidelines (UDGs) provide comprehensive documents that lead to sustainable implementations in the local context. The aim and content of a UDG can differ according to the vision, aim, and associated urban plans. The most common UDG approaches in the world are prescriptive, advisory, and performance-based in order of their appearance in time. The UDGs have been applied in the United States and the United Kingdom since the beginning of the 20th century with the ultimate goal of architectural coherence a nd environmental sustainability. However, their use is relatively very recent in developing countries, including Turkey. Therefore, this study aims to investigate three common types of UDGs in the context of Turkey and provide a deeper understanding their role in achieving urban sustainability from a country-specific perspective.

Design/Methodology/Approach

Seven UDGs have been found that provides a complete process and an extensive content. Three examples, Izmir Kemeraltı Prescriptive UDG, Rize Advisory UDG, and Gaziantep Bizimşehir Performance-based UDG met the selection criteria of comprehensive content, data accessibility, complete process, and comparability and examined in detail. The examples were evaluated and compared according to their integration into the urban planning system and evaluated based on aggregated sustainability criteria. Sustainability criteria set aggregated based on three sustainability frameworks - European Green City Tool, Urban Sustainability Indicators, and Leadership in Energy and Environmental Design Neighborhood Development (LEED-ND) - applicable to Turkey. Two out of seven UDG examples from Turkey and 11 out of 23 sustainability frameworks from the World could not be investigated further as a result of inaccessible data.

Findings

As a result, Gaziantep Bizimsehir Performance-based UDG achieved the highest score in the overall criteria aggregated from existing and common frameworks in the world.

Research Limitations/Implications

It is important to validate the findings by an evaluation of locally defined sustainability criteria for Turkey. However, there is a lack of well-defined publicly available data.

Originality/Value

The results provided the first comprehensive evaluation of three common types of UDGs in the Turkish context. This study presents a detailed framework for future applications not only in Turkey but also in other regions with the similar context.
\end{abstract}

Keywords: Urban design guidelines, prescriptive, advisory, performance-based, urban sustainability 


\section{INTRODUCTION}

In the early 20th century, the dominant urban planning approach was the harmonizing structures and functions associated with physical forms and aesthetics (Symes and Pauwels, 1999; Hall,1996). After the shift from physical urban planning to sustainable urban development in the late $20^{\text {th }}$ century, this approach evolved into an integrated and holistic urban development strategy. This new approach increased the importance of contextuality, and the planning process became more related to the local values such as social equality, identity, risks, and resources. The applications of such a holistic process stand in between users, decisionmakers, socio-economic policies, and environmental strategies. Urban Design Guidelines (UDGs) help manage the complexity of this process as complementary documents that integrated into urban planning. These documents provide a process-oriented, multidisciplinary framework that is coherent with local geographical conditions, strategic frameworks, and urban plans (Gürler, 2018; Kenttam, 2016a). UDGs support local strategies and enhance contextual implementations by guiding the preparation and implementation of urban design projects (Kenttam, 2016a). They include a comprehensive framework of principles and measurements that can increase the sustainability performance of the designated area. Preparation and implementation of UDGs can be required by law or local regulations. The integration of urban design guidelines into the urban planning process primarily took place in the 1970s in the United Kingdom (Punter, 1996) and was followed by the United States in the 1990s (Punter, 1999). However, the first applications in Turkey did not occur until the last decade. The first steps were taken in Turkey in the early 2000s by additional articles to existing laws and regulations. These were followed by extensive government funded projects for the preparation of UDGs (Kenttam, 2016a, 2016b, 2016c), the definition of national spatial standards (Kenttam, 2017), and preparation of performance-based UDGs (HT-TTM, 2018c).

Today, Turkey still has an important position regarding the urbanization and construction sector in the Middle East and Northern Asian countries. On the other hand, to the best of the authors' knowledge, no study has been done specifically for Turkey that explores the UDGs and their implementations in Turkish cities. Therefore, this study aims to develop a thorough understanding of the essential role of UDGs in an urban planning process and its impact on achieving sustainability in the local context. The study provides a detailed review of the existing UDG applications in Turkey and evaluates different approaches to explore their input into sustainable urban development. The study contributes to the literature by answering the following questions. How did UDGs evolve in the Turkish context? How do different UDG types contribute to the sustainable urban development? What is the level of integration for different types of UDGs into the urban planning processes? By answering these questions, this study; 1 ) fills the gap in the literature by providing the first extensive UDG study in the context of Turkish urban planning 
system and sustainable urban development vision 2) provides a systematic framework that will guide future applications for the selection of coherent UDG approach based on the local sustainability targets not only in Turkey but also in other similar contexts.

The following chapter, the evolution of UDG approaches in relation to sustainable urban development is reviewed from a historical perspective, and the research methodology is presented. Examples for each UDG approach are examined in detail in the third chapter. In the fourth chapter, the results are discussed based on the evaluation and comparison of the selected UDGs according to sustainability criteria. This is followed by the conclusion and recommendations for future UDG applications in the fifth chapter.

\section{BACKGROUND AND METHODOLOGY}

Urban design shapes the urban environment by utilizing innovative tools and methodologies that integrate social diversity, environmental responsibility, and economic vitality. An effective urban design process bridges the gap between urban planning and architecture and integrates spatial quality with local characteristics. In this process, UDGs create a common platform for all stakeholders by defining innovative tools, contextual measurements, and inter-scale principles that guide efficient and sustainable development. They can differ depending upon intended deliverables (Shirvani, 1990; Hall, 1996, Karaman, 1999). In this scope, UDGs can provide prescriptive codes that aim to maintain certain characteristics of a designated area. The prescriptive approach involves strict rules and measurements. These documents support urban planning by defining the necessary principles and tools to achieve coherence in architectural design elements such as building materials, colors, height, and volume (Hakim, 2008; Kenttam, 2016a; Lang, 1996). The prescriptive UDGs were firstly applied in the United States and the United Kingdom in the early $20^{\text {th }}$ century, and they provided the most common examples of UDGs. However, the approach became insufficient to provide inclusive principles of sustainability with the rise of the concept. In the late 90 s, the advisory UDG approach relieved the strict framework of the prescriptive UDGs. Advisory UDGs were applied as a separate document that briefly introduces sustainability and its applications within the local context. This approach mainly aimed to inform various stakeholders about the principles, tools, and examples of sustainability and guide local implementations (Hakim, 2008; Kenttam, 2016a). These UDGs can focus on a thematic scenario such as a coastal plan or emphasize a particular pillar of sustainable development such as environmental quality (Kenttam, 2016a; Lang, 1996).

Different from the first two types of UDGs, the performance-based approach was developed to gain a comprehensive framework. Therefore, the performance-based UDGs were developed to encompass all environmental, social, and economic aspects of sustainability. These UDGs provide detailed information about appropriate methods and 
necessary measurements to achieve sustainable development at architectural, regional, and urban scales coherently with the urban development vision. The preparation of performance-based UDGs requires a multürlerdisciplinary and inclusive approach. In this way, the aesthetic-oriented urban design approach in the preliminary UDGs shifted to integrated applications that aim to outperform sustainability criteria including local identity, protected biodiversity, increased energy efficiency, and pollution control (Dogan, 2020; Gürler, 2018; Symes \& Pauwels, 1999; Yalçıner Ercoşkun \& Karaaslan, 2011).

The background research reveals that UDGs are often associated with urban planning trends and used as a tool to achieve sustainability to different extend. For example, the prescriptive approach is applied to sustain the architectural character of a region, the advisory UDG approach emphasizes a particular pillar of sustainability within a specified urban development theme such as an eco-city, and the performance-based approach is applied to bring social, economic, and environmental aspects of urban sustainability together. UDGs have become a tool for urban planning practices in developing countries, including Turkey. However, there is a lack of studies in the literature, which focuses on the evolution and implementation of three main approaches from a country-specific perspective.

\section{Methodology}

This study aims to develop a thorough understanding of the essential role of UDGs in achieving urban sustainability in the local context of Turkey. Therefore, it intends to bridge the gap in the literature by providing a new contextual perspective for the evolution and implementation of UDGs. In this framework, this study is structured in two phases (see Fig. 1). In the first phase, the UDG framework in Turkey is discussed regarding national strategies and current approaches. Three examples are explored in detail to provide a better understanding of the UDG context in Turkey. UDG applications are still only a few, and accessibility to these documents is limited. Thus, examples from each UDG approach were selected among the existing applications and within data availability. After structural research on the existing UDGs which are integrated into an urban planning process, seven examples were found and evaluated in terms of the accessibility of complete and extensive documentation, best representation (relation to the urban planning process and involvement of the local planning authorities) of the local use case, and comparability of scale (see Table 1). Two examples were eliminated because of the lack of accessibility of materials, and two provided only limited content which was not comparable with the sustainability framework. The overall review validated the scarcity of UDG applications in Turkey as a part of the urban planning practice. It was also observed that the change in the UDG approach over time paralleled the participation in the developed countries. As a result of the review of existing examples, Izmir Kemeralt prescriptive UDG, Rize Urban Design Vision (as known as Rize advisory 
A Review of Urban Design Guidelines in Turkey and The PerformanceBased Approach for Sustainability

UDG), and Gaziantep Bizimşehir performance-based UDG were selected for further exploration (see Table 1).

Figure 1. Workflow

The paper is structured in two phases: a review of urban design guideline applications in Turkey and their evaluation according to the sustainability criteria.

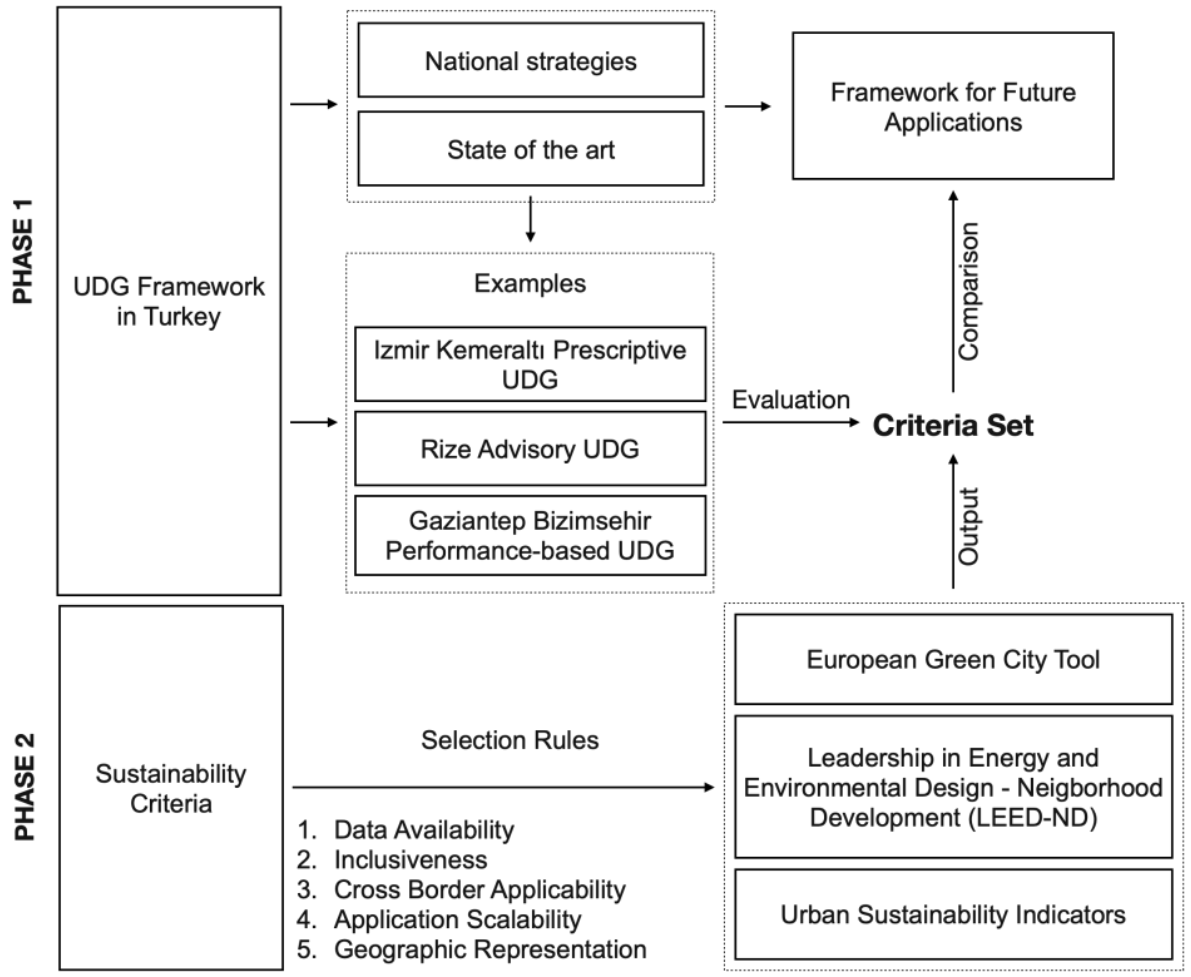

In the second phase of the study, the selected examples were evaluated according to urban sustainability criteria. The criteria set was determined based on common sustainability assessment frameworks. 26 common sustainability indicator frameworks (European Commission, 2018) were reviewed according to data availability, their inclusiveness of sustainability dimensions, cross-border applicability, application scalability, and geographic representation (see Fig. 1, Table 2) to obtain a criteria set applicable to Turkey.

As a result, three frameworks - European Green City Tool (European Commission, 2020), Urban Sustainability Indicators (Mega \& Pedersen, 1998), Leadership in Energy and Environmental Design Neighborhood Development (LEED-ND) (CNU et al., 2011) - were selected for further evaluation. Each framework provided common and contextual categories and criteria. The categories in the local context were included in the evaluation table as subcategories (see Table 3). For example, character and identity are only covered by Urban Sustainability Indicators (Mega \& Pedersen, 1998), thus it was considered as the subcategory of the urban design quality. The criteria of the selected frameworks provided seven categories, 'urban planning, urban design quality, mobility, security, environmental quality, green growth and innovation, and governance'. These were later divided into seven subcategories where necessary. The matrix involve 91 criteria in total (see Table 3). 
Table 1. The review of existing UDGs in Turkey that are implemented as a part of an urban planning process and/or by the involvement of a responsible local planning authority. Rows in Gray show the selected examples (Created by the authors for this paper)

\begin{tabular}{|c|c|c|c|c|c|c|}
\hline $\begin{array}{l}\text { UDGs (integrated to the urban } \\
\text { planning process) }\end{array}$ & Year & Type & Content & $\begin{array}{l}\text { Accessibility of } \\
\text { the document }\end{array}$ & Completeness & Scale \\
\hline $\begin{array}{l}\text { Izmir Kemeraltı Kentsel Tasarım } \\
\text { Rehberi (Izmir Kemeraltı UDG) }\end{array}$ & 2002 & Prescriptive & $\begin{array}{l}\text { Architectural } \\
\text { sustainability / } \\
\text { conservation }\end{array}$ & Accessible & Completed & Urban region \\
\hline $\begin{array}{l}\text { Tarsus Tarihi Ticaret Merkezi } \\
\text { Kentsel Tasarım Projesi } \\
\text { Yapılassma Rehberi (Tarsus } \\
\text { Historical Commercial Center } \\
\text { Urban Design Project Settlement } \\
\text { Guideline) }\end{array}$ & 2006 & Prescriptive & $\begin{array}{l}1 / 5000 \text { and } 1 / 1000 \text { urban } \\
\text { plan notes }\end{array}$ & Accessible & Completed & Urban region \\
\hline $\begin{array}{l}\text { Fatih Belediyesi Kentsel Tasarım } \\
\text { rehberi (Fatih Municipality UDG) }\end{array}$ & 2012 & Prescriptive & Transportation & Accessible & Completed & Urban region \\
\hline $\begin{array}{l}\text { Galata Bölgesi Kentsel Tasarım } \\
\text { Rehberi (Galata Region UDG) }\end{array}$ & 2013 & Prescriptive & $\begin{array}{l}\text { Architectural } \\
\text { sustainability / } \\
\text { conservation }\end{array}$ & Not accessible & Completed & Urban region \\
\hline $\begin{array}{l}\text { Sürdürülebilir İstanbul Kentsel } \\
\text { Tasarım Rehberi (Sustainable } \\
\text { Istanbul UDG) }\end{array}$ & 2017 & Advisory & $\begin{array}{l}\text { Social, economic, } \\
\text { environmental } \\
\text { sustainability }\end{array}$ & $\begin{array}{l}\text { Partially } \\
\text { accessible }\end{array}$ & NA & $\begin{array}{l}\text { Metropoliten } \\
\text { region }\end{array}$ \\
\hline $\begin{array}{l}\text { Rize Kentsel Tasarım Vizyonu } \\
\text { (Rize Urban Design Vision) }\end{array}$ & 2017 & Advisory & $\begin{array}{l}\text { Environmental } \\
\text { sustainability }\end{array}$ & Accessible & Completed & Urban region \\
\hline $\begin{array}{l}\text { Gaziantep Bizimşehir Kentsel } \\
\text { Tasarım Rehberi (Gaziantep } \\
\text { Bizimşehir UDG) }\end{array}$ & 2018 & $\begin{array}{l}\text { Performance- } \\
\text { based }\end{array}$ & $\begin{array}{l}\text { Social, economic, } \\
\text { environmental } \\
\text { sustainability }\end{array}$ & Accessible & Completed & Urban region \\
\hline
\end{tabular}

Table 2. Review of Urban Sustainability Indicator Frameworks (The list of frameworks obtained from European Commission, in-depth report: Indicators for sustainable cities (2018)). Rows in Gray show the selected examples (This table created by the authors for this paper)

\begin{tabular}{|c|c|c|c|c|c|}
\hline Urban Sustainability Framework & $\begin{array}{l}\text { Data } \\
\text { accessibility }\end{array}$ & Inclusiveness of indicators & $\begin{array}{l}\text { Cross-border } \\
\text { applicability }\end{array}$ & $\begin{array}{l}\text { Application } \\
\text { scalability }\end{array}$ & $\begin{array}{l}\text { Geographic } \\
\text { representation }\end{array}$ \\
\hline China Urban Sustainability Index & - & Environment & NA & v & Asia \\
\hline City Blueprints & $\checkmark$ & Water management & $v$ & - & Global \\
\hline EEA Urban Metabolism Framework & - & Environment & - & $\mathrm{v}$ & Europe \\
\hline European Green Capital Award & $\checkmark$ & Environment, Governance & - & $\checkmark$ & Europe \\
\hline European Green City Tool & $\sqrt{ }$ & Environmental, Social, Economic, Governance & $\sqrt{ }$ & $\sqrt{ }$ & Global \\
\hline European Green City Index & - & Environment & - & $\sqrt{ }$ & Europe \\
\hline European Green Leaf Award & - & Environment & - & $\checkmark$ & Europe \\
\hline Global City Indicators Facility & - & Environmental, Social, Economic, Governance & $\checkmark$ & $\checkmark$ & Global \\
\hline $\begin{array}{l}\text { Reference Framework for Sustainable } \\
\text { Cities }\end{array}$ & $\checkmark$ & Environmental, Social, Economic, Governance & - & $\checkmark$ & Europe \\
\hline STAR Community Rating System & - & Environmental, Social, Economic, Governance & - & $\checkmark$ & United States \\
\hline Urban Audit Cities Statistics & $\checkmark$ & Environmental, Social, Economic, Governance & - & $\checkmark$ & European Union \\
\hline Urban Ecosystem Europe & - & Environment & - & $\mathrm{v}$ & Europe \\
\hline Urban Sustainability Indicators & $\checkmark$ & Environmental, Social, Economic, Governance & $\checkmark$ & $\checkmark$ & Global \\
\hline BREEAM Communities & $\checkmark$ & Environmental, Social, Economic, Governance & $\checkmark$ & $\checkmark$ & Europe \\
\hline Climate Positive Development Programme & $\checkmark$ & Climate & $\checkmark$ & $\checkmark$ & Global \\
\hline Covenant of Mayors & - & Climate, Energy & - & $\checkmark$ & Europe \\
\hline DGNB Certification Scheme & $\checkmark$ & Environmental, Social, Economic, Governance & - & $\checkmark$ & Europe \\
\hline The Eco2 Cities Initiative & - & Environmental, Social, Economic, Governance & $\checkmark$ & $\checkmark$ & Global \\
\hline $\begin{array}{l}\text { Eurostat Sustainable Development } \\
\text { Indicators }\end{array}$ & $\checkmark$ & Environmental, Social, Economic, Governance & NA & NA & Global \\
\hline Green Cities Programme (OECD) & - & NA & NA & NA & Global \\
\hline Green Star & $\checkmark$ & Environmental, Social, Economic, Governance & - & $\checkmark$ & $\begin{array}{l}\text { Australia, New } \\
\text { Zealand }\end{array}$ \\
\hline LEED-ND & $\checkmark$ & Environmental, Social, Economic, Governance & $\checkmark$ & $\checkmark$ & Global \\
\hline NABERS & $\sqrt{ }$ & Environment & - & $\checkmark$ & Australia \\
\hline SDEWES Index & $\checkmark$ & Environment & $\checkmark$ & $\checkmark$ & Global \\
\hline SynCity & - & Environment & NA & NA & NA \\
\hline Urban Indicators Guidelines & $\sqrt{ }$ & Environmental, Social, Economic, Governance & NA & NA & Global \\
\hline
\end{tabular}

The selected examples are discussed in detail in the next section. This follows by the evaluation and comparision of the examples according to the aggragated criteria set.

\section{URBAN DESIGN GUIDELINES IN TURKEY}

The term urban design indirectly takes part in several laws and regulations, and it is institutionalized by only a few municipalities in Turkey. The integration of the urban design process into the urban planning system was defined for the first time in 2009 in the Integrated 
Urban Development Strategy and Action Plan 2010-2023 (Republic of Turkey, Ministry of Environment and Urbanisation, 2010a). In this scope, urban design is considered together with urban heritage, conservation, and spatial quality. It is stated in the document that urban design is a separate profession that should be integrated into the urban planning process and work together with the other disciplines. Preparation of a UDG booklet and presenting related urban design standards were defined as necessary actions for achieving this integration (Kenttam, 2016c; Republic of Turkey, Ministry of Environment and Urbanisation, 2010b). This approach encouraged local governments to prepare UDGs. In 2016 the emphasis was given to the importance of UDGs in an urban planning process. This was strengthened by the 'Preparation of Urban Design Guidelines' project (Kenttam, 2016a, 2016b, 2016c) which was funded by the Republic of Turkey, Ministry of Environment and Urbanisation.

As described in the previous section, the early applications of UDGs have prescriptive features with a rule-based framework. These prescriptive UDGs are generally used for the restoration and planning of historical areas. These type of UDGs illustrates essential architectural details that cannot be included in master plans. In Turkey, the prescriptive approach constitutes the most common UDG method and is occasionally prepared by local governments as a necessary attachment of conservation plans. İzmir Kemeraltı UDG (Dokuz Eylül University Department of City and Regional Planning, 2002, 2009) is a complete and extensive example for the implementation of prescriptive UDGs. The UDG was prepared in two stages as complementary documents of Kemeraltı first and second stage conservation plans. These documents consisted of detailed architectural measurements and design rules. The content reflects the existing authentic elements in architecture and aims to protect and sustain physical characteristics. The documents are a result of a collaborative process between university and the municipality.

Rize Urban Design Vision was prepared with the university - local government collaboration and openly published by the municipality a year after the government actions towards enhanced and integrated urban design processes in the planning system (Kenttam, 2016a, 2016b, 2016c). The document provided a preliminary example for advisory UDGs in Turkey that guides sustainable regeneration of the city's coastline. The UDG involves the illustrations of existing implementations from similar cases, region-specific conceptual diagrams, and recommendations.

Since 2015, the urban design practice in Turkey is under influence of a performance-based urban planning approach towards urban sustainability. The approach has occurred as a way to achieve sustainability through effective monitoring and assessment (Dogan, 2020). The applications of the performance-based approach started to expand at the beginning of the 2000s. However, its influence in Turkey was not occur until the increasing trend of sustainability certification (e.g. in LEED (CNU et al., 2011)). UDGs are recognized as an essential element 
in this approach for the translation of sustainability criteria into urban design principles. Bizimşehir Gaziantep UDG (HT-TTM, 2018c) is one of the first examples in Turkey that achieves this role. The UDG provides a detailed framework for the local design principles, necessary tools, and alternative solutions for smart and sustainable development. It was prepared as a part of the urban planning process and according to national and local sustainability targets. In the following section, these three UDG examples are explored more in detail to provide a better understanding of the implementation of three dominant approaches in the Turkish context.

\section{İzmir Kemeraltı Conservation Plan $1^{\text {st }}$ and $2^{\text {nd }}$ Stage Prescriptive UDGs}

İzmir Kemeraltı UDG was prepared in two stages attached to the 1:5000 and 1:1000 Conservation Plan Revisions by İzmir Konak Municipality in 2002 and 2009. The UDG was developed in collaboration with the municipality and the Dokuz Eylül University, City and Regional Planning Department. Both plans and UDGs aimed to protect the historical patterns of the conservation site and to sustain its local character in the future (Dokuz Eylül University Department of City and Regional Planning, 2002). An extensive building survey was conducted for the UDG to determine the unique architectural elements in the region. The document is structured in five main chapters, 'commercial buildings, typical residential buildings, structures with Turkish architectural style, early republican period buildings, and building components within the area'. Commercial buildings were analysed as single commercial units, inns with inner passages and courtyards, and mixed-use buildings. They were examined related to the number of floors and their land uses. The representations were supported by interior plans. As part of the traditional Anatolian architectural unit, inns are introduced according to types of courtyards and inner passages (see Fig 2). Building typologies for commercial buildings were examined and represented with detailed hand-drawn visualizations.

In chapter two, the residential buildings in the urban conservation site are represented with 1:100 scale detailed floor plans presenting the plot and building compositions and measurements (see Fig. 2). Material and building form information has been given in the text. Façades that represent the local characteristics are imprinted into the drawings at the single building scale (see Fig. 3). 
A Review of Urban Design Guidelines in Turkey and The PerformanceBased Approach for Sustainability

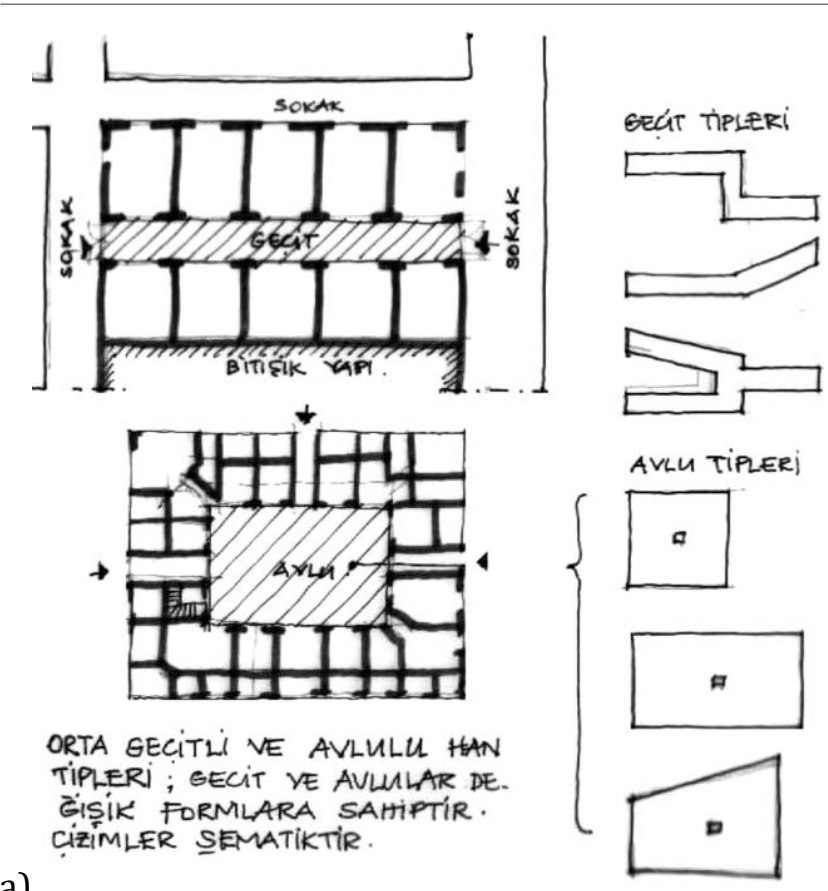

Figure 2. Examples from the analysis of local building typologies a) Typology of inner passages and courtyards for inns b) Typology of commercial building converted from a residential building (Dokuz Eylül University Department of City and Regional Planning, 2002). For the translations see appx. 1.

a)

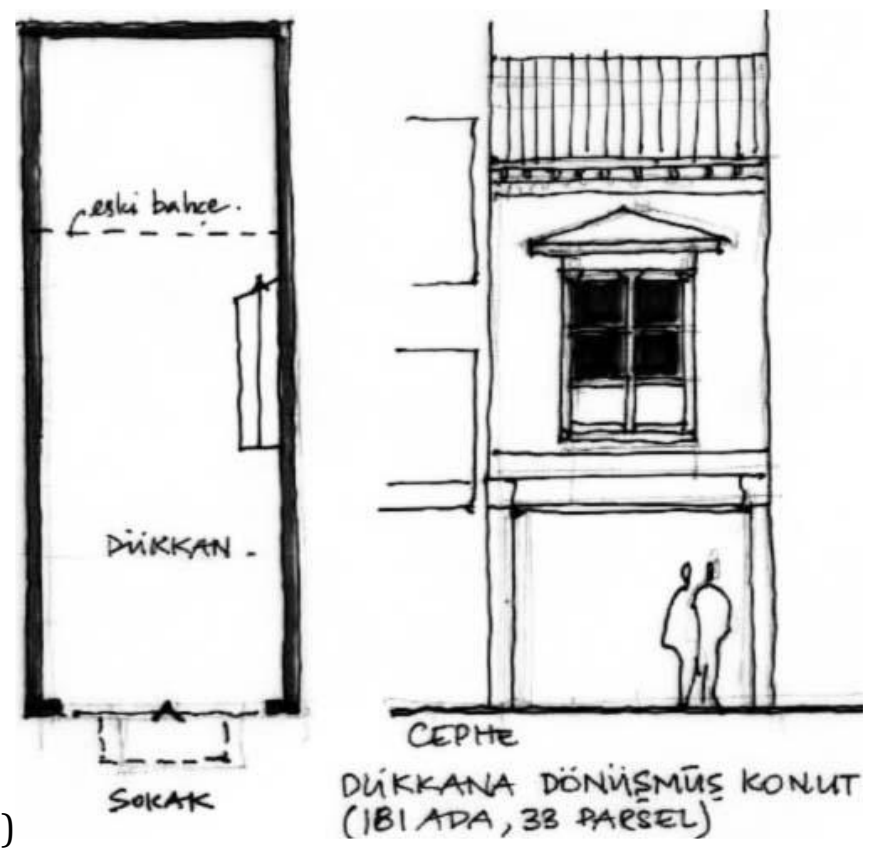

The features of the traditional Turkish residential building style are described in the third chapter of the document. According to the site surveys, narrow streets and cul-de-sacs in an organic pattern represent the neighbourhood morphology. Streets are surrounded by timber buildings that directly opens to streets without a passage through a courtyard.

The fourth chapter involves the building typologies for the early Republican Period. This chapter mainly focuses on the structural details that characterize the architectural epoch and its visualizations (see Fig. 4a). The fifth chapter introduces the individual architectural elements in detail, including doors and windows, balconies, shutters, street furniture, 
signs, and colours. The architectural details are given in the 1:20 scale drawings in this section. Each element is classified according to its specific typology, material, and location-based information in the urban conservation site. Individual elements such as shutters are schematized according to aesthetic rules and display. For example, building entrances are examined according to different typologies, height, ornaments, and their relation to the street (see Fig. 4b).

\section{iki RATS PLAN TiPi \\ ZEMIN KAT PLANI Ö: $1 / 100$}

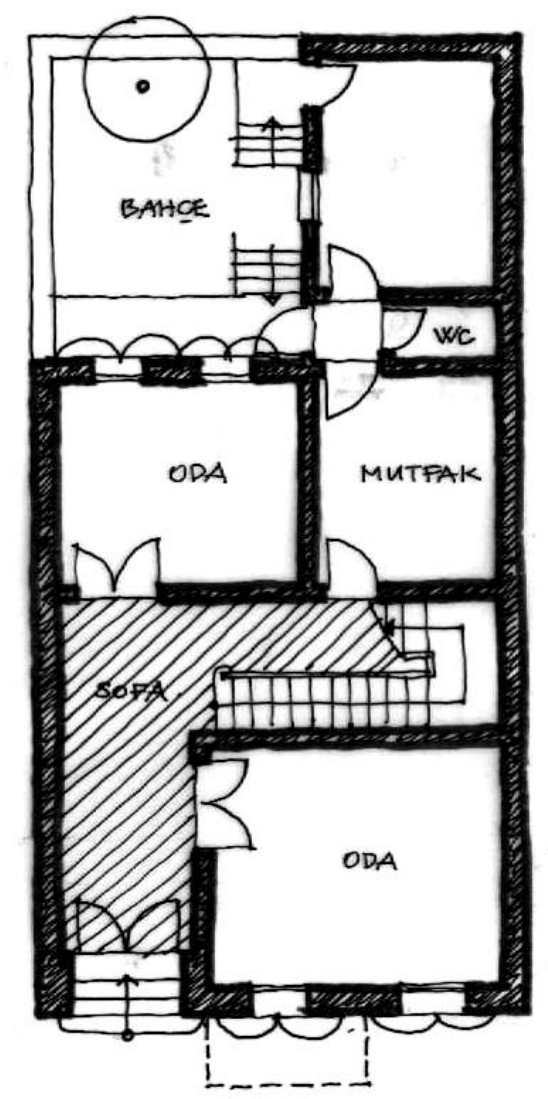

BIRINCI KAT PLANI Ö $1 / 100$

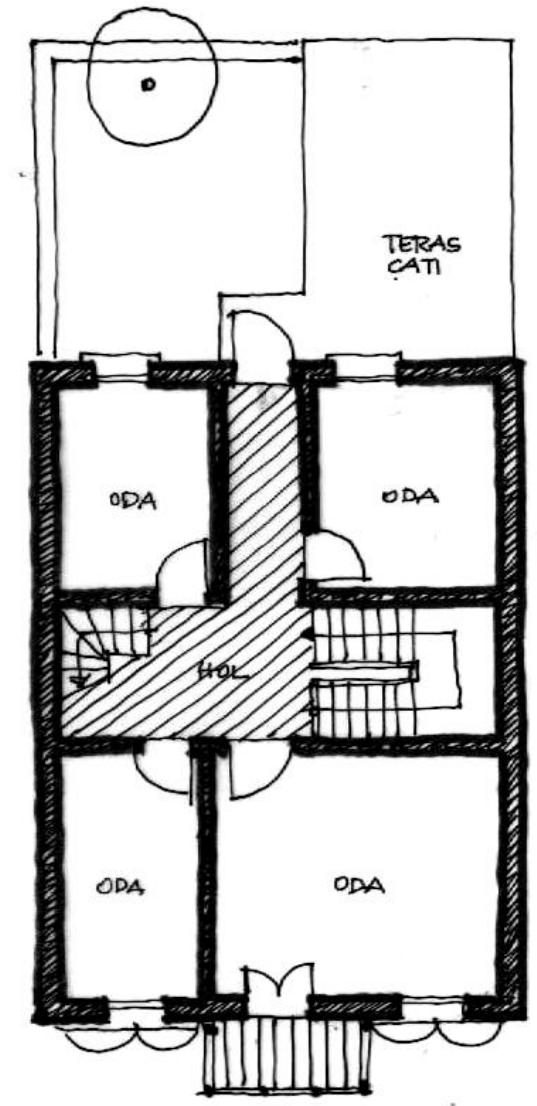

Figure 3. Examples from the analysis of local building typologies for ground and first floor plans of residential building (Dokuz Eylül University Department of City and Regional Planning, 2002). For the translations see appx. 1.

Building and garden entrance doors, railings, jambs, decorative horizontal profiles, chimneys, birdhouses, and other decorative elements such as sculpture niche, forehead walls, flower beds, and ridge tiles are described in detail. A 28-color palette is given based on their appearances on the building exteriors to be used in future applications for visual order and harmony of the structures and space. The schemas and views are given at a 1:10 scale for common materials and forms of eaves and awnings on the buildings. The alternatives for street furniture including pergolas, billboards, signs for streets and shops, benches, light poles, 
Figure 4. Examples from authentic building details on materials and structure a) Street-building relation for traditional Turkish residential buildings b) building entrance door. (Dokuz Eylül University Department of City and Regional Planning, 2002). For the translations see appx. 1.

Figure 5. Examples, details, and measurements of a) horizontal signs b) bench, garbage bins, and flowerpots (Dokuz Eylül University Department of City and Regional Planning, 2002). For the translations see appx. 1.
A Review of Urban Design Guidelines in Turkey and The PerformanceBased Approach for Sustainability

waste containers, flowerpots, water elements are given in detail with measurements (see Fig. 5 and 6).
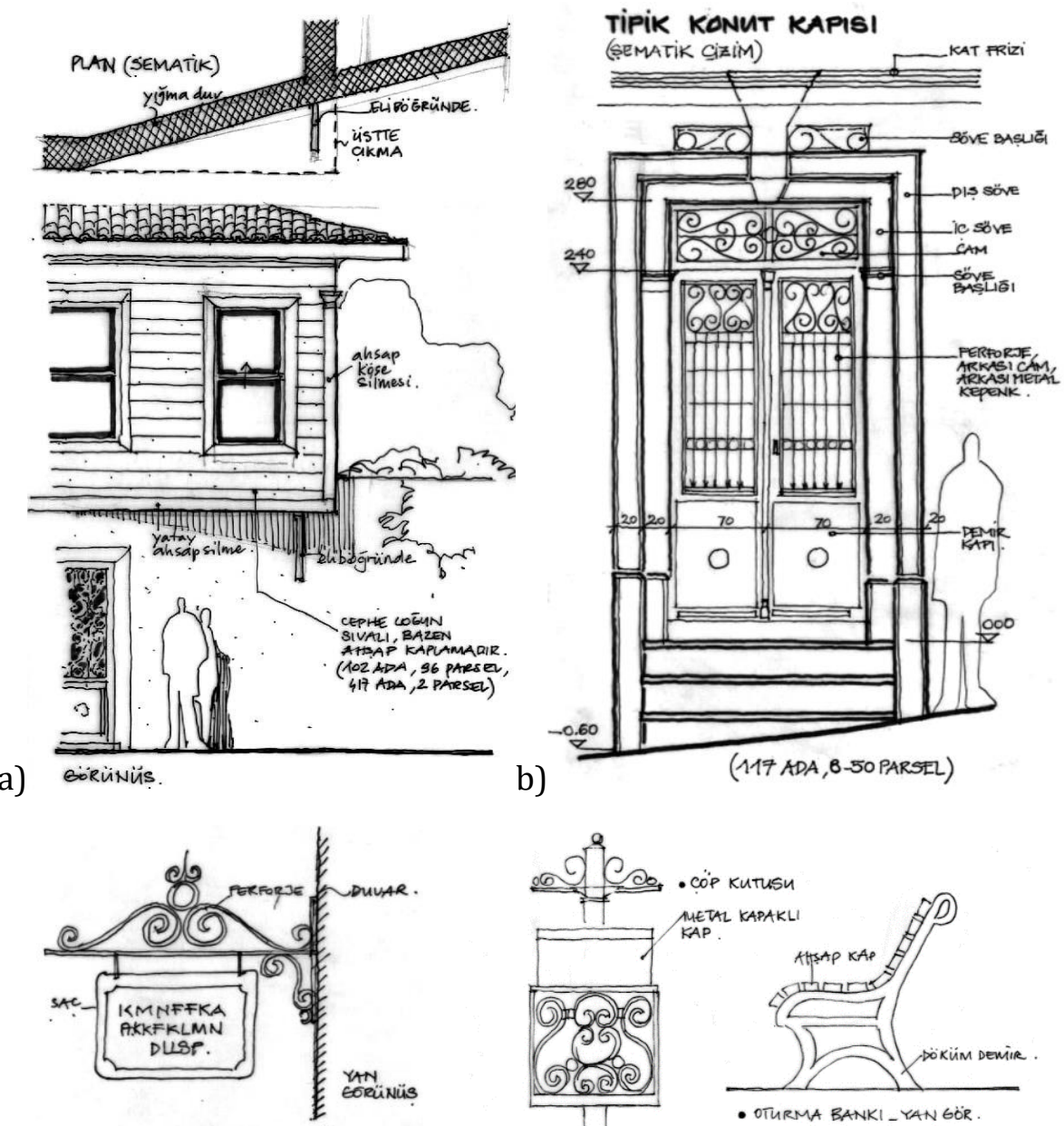

296

a)

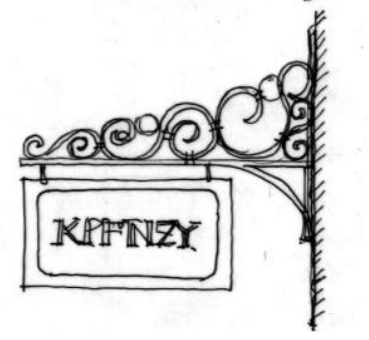

b) • CicekLiK YAN Görinuis

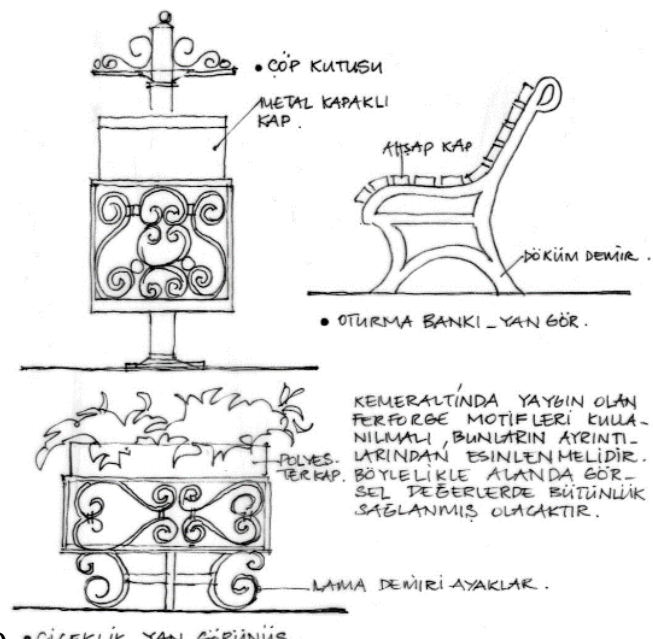

The alternative design principles in İzmir Kemeraltı $1^{\text {st }}$ stage UDG were emphasized in the $2^{\text {nd }}$ UDG (Dokuz Eylül University Department of City and Regional Planning, 2009). Greek and Levantine style structures were added in the second document. Different from the first UDG the visualizations are supported by photographs and digital drawings in the $2^{\text {nd }}$ stage (see Fig. 7).

İzmir Kemeraltı prescriptive UDGs were prepared based on analyzes and typological studies of civil architectural examples. They revealed existing features as alternative design components to guide future applications. These documents are important to sustain the same architectural approach throughout the designated area, especially in conservation sites. However, socio-economic and environmental factors are very limited as in the example. Although these two documents provided 
extensive information over the physical structure to guide future constructions and were prepared by a group of planners, the focus was kept on the building scale and comprehensive sustainability was not mentioned or aimed. Despite the prescriptive UDGs are common, they became insufficient to meet the increasing focus on sustainable urban development in Turkey especially since 2009. In this scope, nextgeneration advisory and performance-based UDGs provide more integrated and interdisciplinary processes to fulfill this gap between the urban sustainability targets and urban design applications.

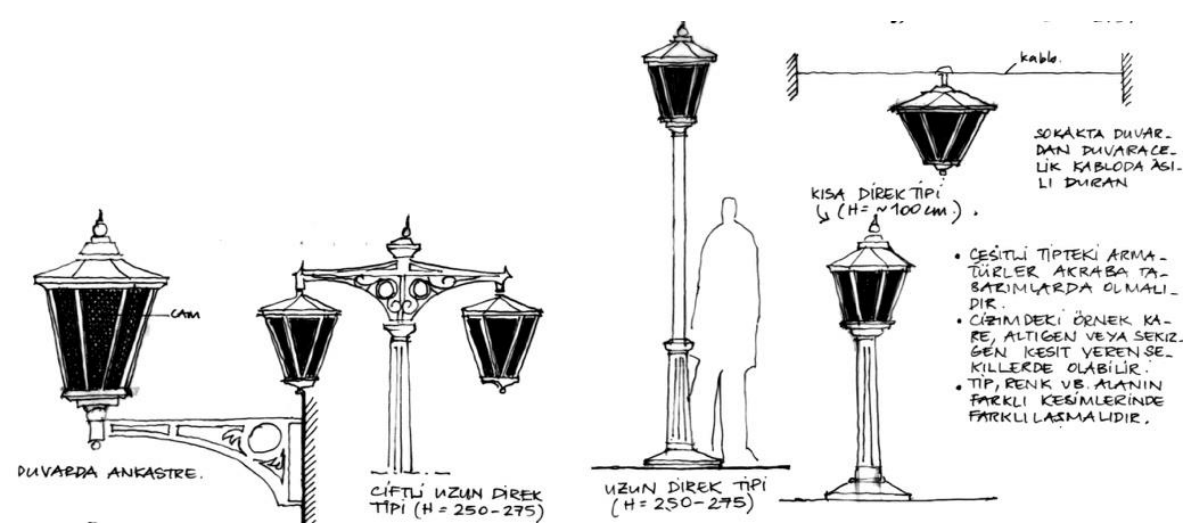

a)
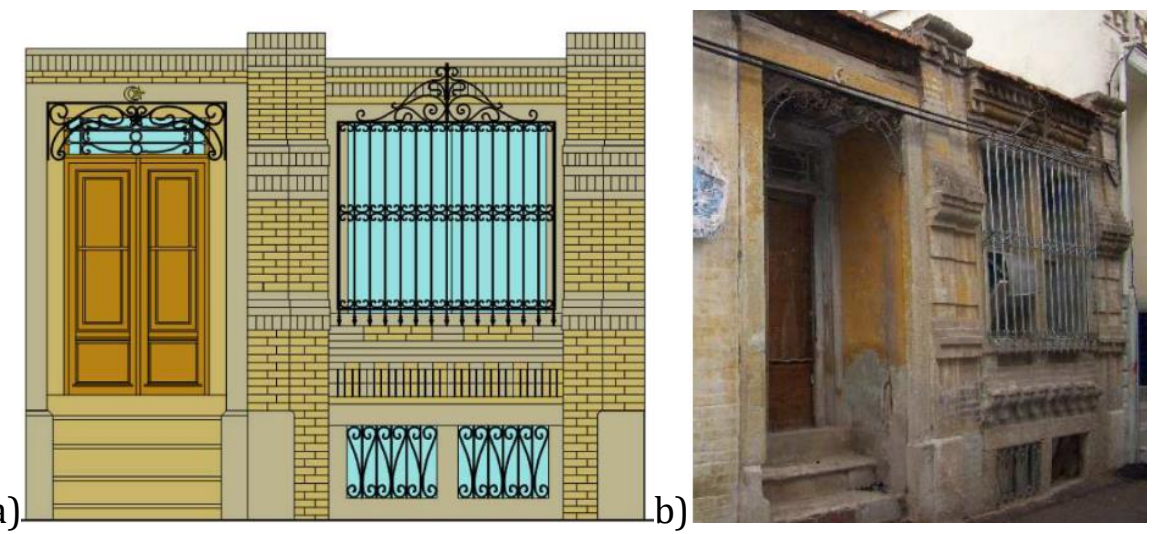

\section{Rize Advisory UDG}

Rize Advisory UDG was prepared in 2017 (MSGSÜ, 2017) by a multidisciplinary team from Mimar Sinan Fine Arts University upon the request of Rize Municipality. The project team included urban designers and architects. The Rize advisory UDG targeted the urban design projects in the city's coastal area (see Fig. 8) by focusing on the New Coastline Urban Design Project. The document aims to provide a better understanding of necessary strategies, procedures, and tools for the preparation of design projects. It includes brief information, conceptual schemas, and project examples. Although the guideline is not binding nor a part of a master plan, it was prepared according to the Rize Local Environment Action Plan and aligned with its vision for Eco-city development. Therefore, the strategic vision of the city is defined as ' Rize,
Figure 6. Examples, details, and measurements of different type of lightening. (Dokuz Eylül University Department of City and Regional Planning, 2002). For the translations see appx. 1.

Figure 7.a) The model and b) the original of Greek and Levantine style façade (Dokuz Eylül University Department of City and Regional Planning, 2009). 
the eco-city that provides social development-oriented life, solves problems at its source, produces solutions, protects cultural values, and exists with natural environment' (MSGSÜ, 2017). In the first section of the guideline, the definitions, principles, and methods for urban design projects are given. This is followed by the evaluation of the characteristics of the city based on the built environment, natural structure, transportation, and coastline. After the definition of the method and local characteristics of the city, the strategies, tools, and procedures are defined for the Rize New Coastline Urban Design Project in the third section (MSGSÜ, 2017).

The main urban design principles are gathered under eight categories: 'identity and originality, water and accessibility, environmental sustainability, balance and integration, diversity and flexibility, economic improvement, communication and mobilization, urban design quality. General definitions, strategical principles, subsections, urban design projects, tools, and application opportunities are explained as a part of the urban design method.

The general definitions include analyzes, vision, strengths, weaknesses, and the stakeholders involved in the design process. Strategical guidance encompasses the analysis of the public spaces and identity elements based on cultural infrastructure and ecological environments, and gives abstract and concrete details about them. Subsections define necessary actions such as conceptual schemas, detailed design projects, thematic design guidelines, public participation methods, funds and financial supports, and process management towards the local framework.

In the scope of the UDG strategies and the concept for the city, the first action for an urban design process is defined as preparing a conceptual schema and definition of the vision. The detailed strategies and related actions are adopted from the Local Environment Action Plan. Therefore, the UDG strategies are built upon actions related to Eco-city Rize vision, aiming to strengthen the natural and cultural heritage, and systematical urban planning. The third section of the guideline is the main part of the document that describes the strategies and work packages to achieve this aim. The section covers definitions and goals specific to district, neighborhood, and architectural levels. Each subsection involves brief information on the actions, normative examples from the world, and supportive visualizations.

At the district level, the prestigious Rize Coastline Urban Design Project is introduced according to energy efficiency, accessibility, and permeability at the district level. The basic principles for the project are determined and visualized (see Fig. 9 and 10) as follows:

- Bringing the city and sea together

- Providing the necessary infrastructure to support tourism,

- Balancing and improving ecological restoration,

- Increasing the urban quality of life,

- Ensuring the vitality of urban life, 
- Providing scientific and technological perspectives for energy and the city,

- Increasing the city's competitiveness,

- Sustaining economic vitality.

In addition to these principles, supporting innovative and creative industries is suggested for 'tea' production as the most important local agricultural product of the city.

a)
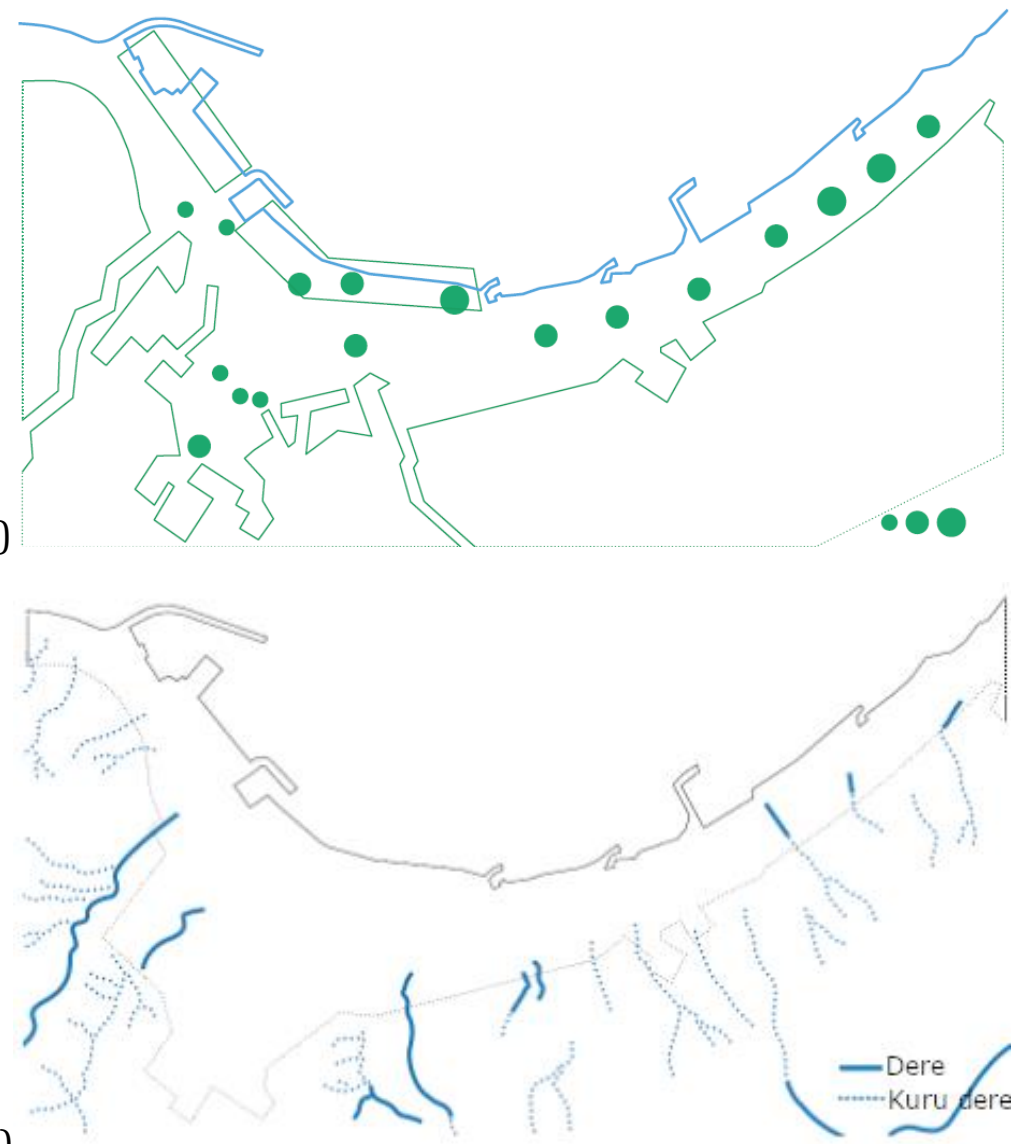

b)

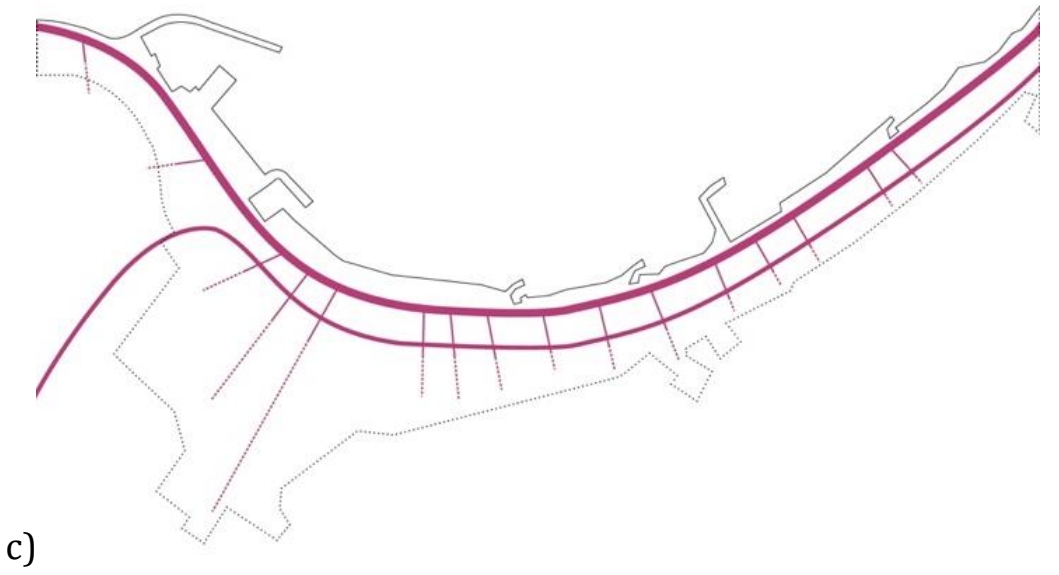

Figure 8. Examples of conceptual urban analysis from Rize Advisory UDG a) Integrated open green area hierarchy b) Protected water bodies in the scope of the Eco-city vision c) Existing transportation network. (MSGSÜ, 2017) (The images are not to scale, $\uparrow$ North).

The next strategy is built upon the neighborhood design and neighborhood design guidelines that will re-evaluate the identity based 
Figure 9. Rize New Coastline Urban Design Project conceptual schema, Urban Gates and integration/relation of different land uses with green areas and the sea (MSGSÜ, 2017) (The images are not to scale, $\uparrow$ North). For the translations see appx.

Figure 10. Rize New Coastline Urban Design Project conceptual schema, Landmarks and the main urban axis (MSGSÜ, 2017) (The images are not to scale, $\uparrow$ North).
A Review of Urban Design Guidelines in Turkey and The PerformanceBased Approach for Sustainability

on social and cultural infrastructure. According to the guideline, the neighborhood unit supports communication and collective actions between different socio-cultural groups and meets the basic needs of modern life by efficient public spaces. Coherent with the local action plan, the emphasis is given to renewable energy and energy efficiency, green building applications, and the historical pattern. At the neighborhood level, design projects and UDGs are emphasized as performance measures for architectural details and space hierarchies.
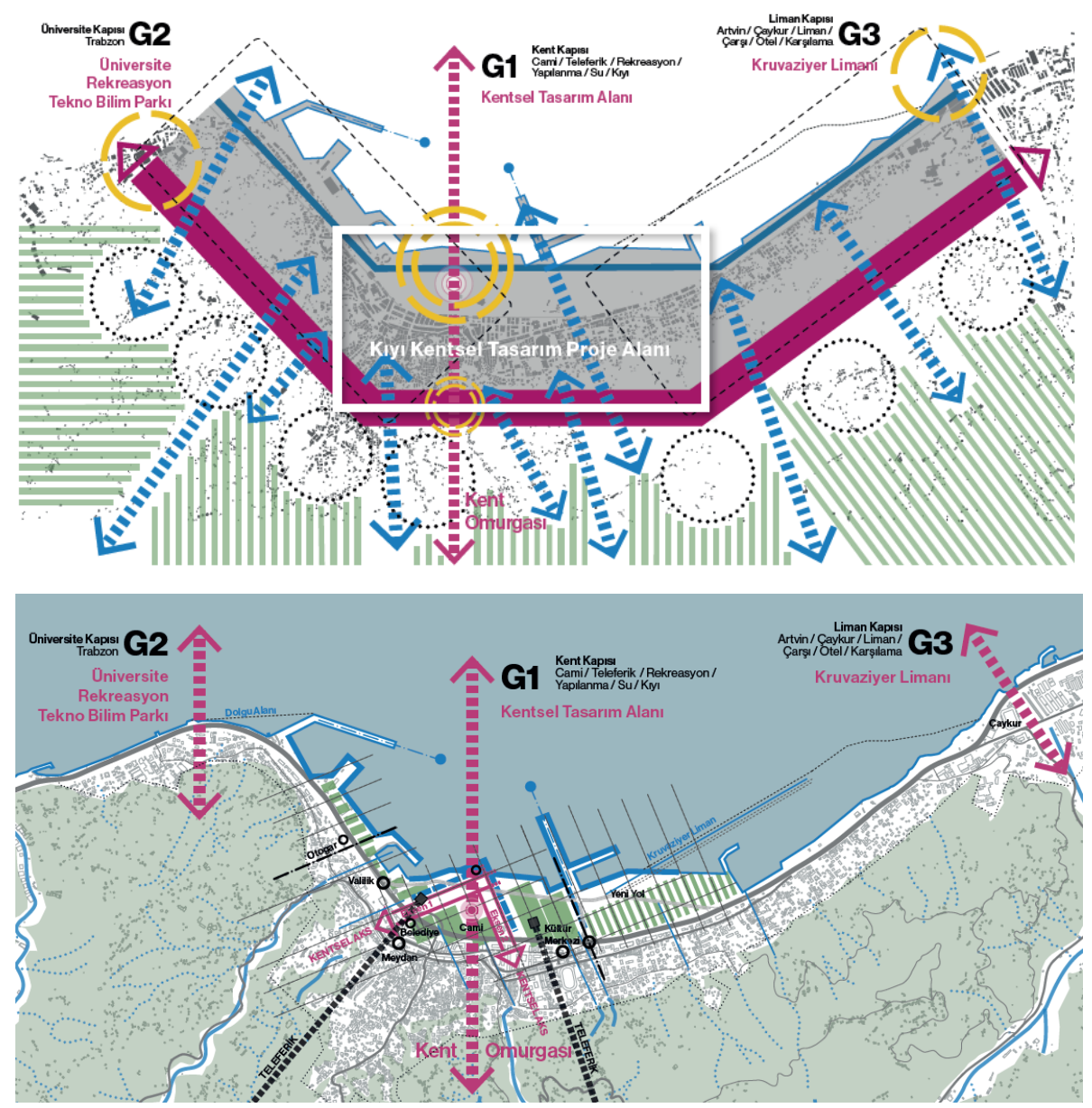

At the architectural level, the prestigious urban axis and façade renewal project is approached within three actions defined in the local action plan. These are related to façade renewal for aesthetical harmony in the city center, contemporary art on the axis, and determination and application of façade standards. The aim of the urban axis project is defined as the revitalization of the main artery of the city for directing and synchronizing the urban development. The main urban design principles are presented as 'integrity in land uses, human-scale environments, pedestrian comfort, and green landscape'.

As a result, the Rize advisory UDG provides the main principles and suggestions for producing urban design projects specific to the region and local vision. It aimed to integrate different stakeholders with strategical spatial planning and urban design. The determination of a common vision for the city in coherence with the local strategies, 
improving the environmental quality, enhancing the identity by neighborhood concept, providing ecological restoration, bringing users, city, green, and coastline together, defining innovative technologies for renewable energy, and supporting urban design as a tool for sustainable urban development defined the main targets of the UDG. These targets are explained briefly and supported by examples for guiding the process management.

\section{Bizimşehir Gaziantep Performance-based UDG}

Bizimşehir Gaziantep Performance-based UDG was prepared in 2018 as a part of a larger project funded by The Republic of Turkey, The Ministry of Environment and Urbanisation. The overall project aimed to plan a green, secure, human-centered, local-driven, and smart settlement for the Şahinbey District in Gaziantep, in the southeast of Turkey (HT-TTM, 2018c). Seven working task forces were formed for 'urban planning and design, architecture, environmental engineering, disaster management, geoinformatics, information technologies, and local consultancy' for achieving this goal. As a part of the urban planning and design task force, the UDG was prepared in coherence with the objectives of the project, upper-scale plans, planning regulations, and related government-funded complementary projects (Kenttam, 2016a, 2016b, 2016c, 2017). The designated area is studied in the UDG within five following subjects, the human-centered city, the city with identity, smart city, green city, and the safe city (HT-TTM, 2018c).

The aim of the UDG is to define urban design principles and related measures for increasing the quality of the built environment and life. The defined principles reflect a comprehensive perspective that focuses on social inclusion, environment sensitivity, economic resiliency, and unique identity. The target group involves designers, developers, local government, and other related stakeholders. The case study area is a 287hectare infill development in Gaziantep metropolitan area planned as a group of mix-use neighborhoods (HT-TTM, 2018b, 2018a). The general approach of the UDG is structured on the reinterpretation of the Gaziantep's inherited urban morphology which is characterized by the harmony between regional topography and central commercial activities. Commercial areas have a dominant place within daily life as neighborhood centers that bring social, commercial, and religious activities together. Based on these characteristics, the urban design principles are determined as 'small urban plots, single-floor shops, natural material use, mix-use and functional relations, environment friendly manufacturing, climate control, and topography-built environment harmony'.

Within the scope of the human-centered city component (see Fig. 11), design principles and measures are elaborated according to integrated transportation, pedestrian mobility and walkability, universal design, open green areas, recreational areas, and playgrounds. 
A Review of Urban Design Guidelines in Turkey and The PerformanceBased Approach for Sustainability

a)

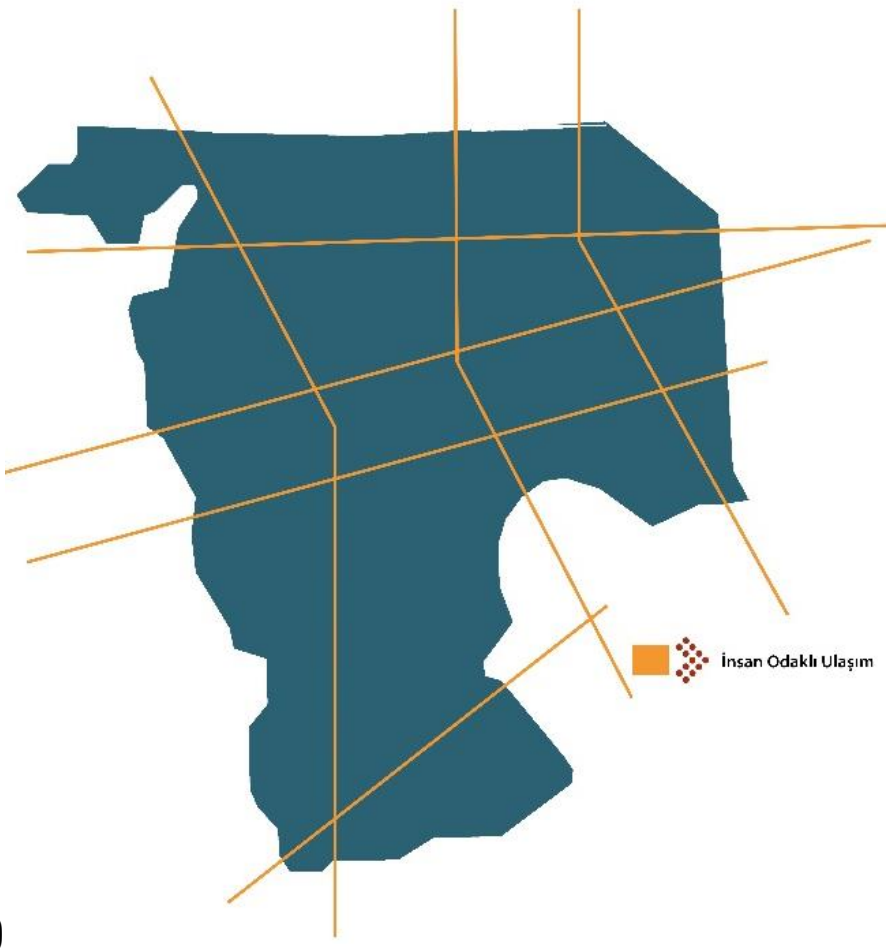

Figure 11. Conceptual schemas for a) humanoriented transportation b) human-oriented center (HTTTM, 2018c). (The images are not to scale, $\uparrow$ North).

For the translations see appx. 1.

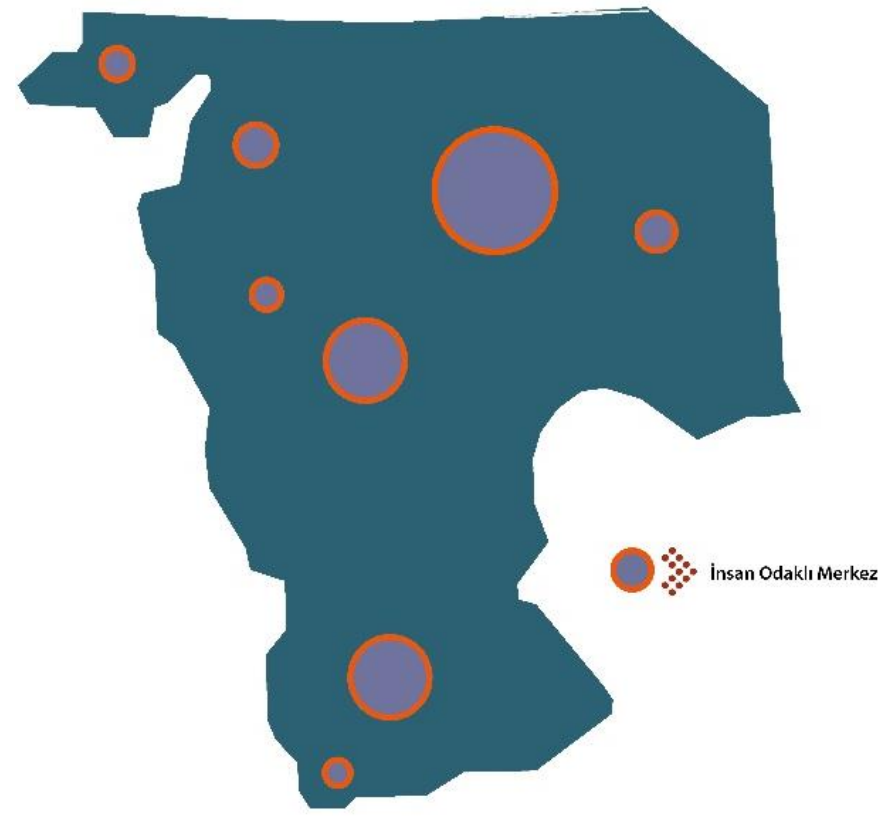

b)

An integrated transportation system aims to increase accessibility to urban functions for every user, therefore, supports the universal design. Public transportation is prioritized throughout the area in the plans to support this aim. Bicycle and pedestrian-oriented routes are designed throughout the settlement. A tramline is also involved in the main arterial road (see Fig. 12). For an effective engagement between these modalities, a typology of proper separations and integrations are presented in the UDG based on the plantation, lineation, and concrete materials. The 
pedestrian ways are supported by green areas and public squares at different scales. These design elements are also used to support the sustainability of the area. Location and the orientation of these areas are defined according to the wind corridors for climate control. The permeable landscape elements are suggested for rainwater collection, pedestrian safety, air quality, and noise reduction purposes.

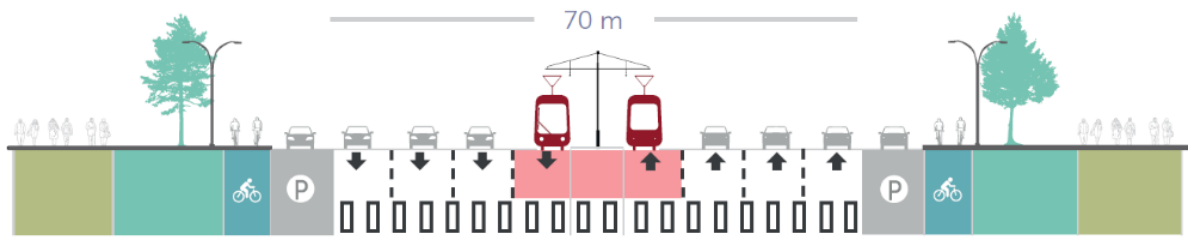

The necessary measures and standards for the bicycle routes and parking are given in the UDG for topographic elevation, security, signage, lighting, lanes, and parking stations. Accessibility measures are considered according to the universal design principles that aim to increase mobility primarily for children, disadvantaged and senior people. Education, daycare, and health facilities are suggested within the $400 \mathrm{~m}$ walking distance to the public transportation stops.

The human-scale building architecture is one of the essential components in the UDG and architectural design. Alternative design approaches are developed by the architectural design team for cluster housing and single-family homes. A modular approach was applied for the residential buildings (see Fig. 13). The ratio of solid and transparent surfaces, the colors, and materials on façades are brought together in the UDG to support the human-scale and climate control. Social communication and public participation between citizens and stakeholders are supported in design by facilities such as a culture, art, and public education center, exhibition areas, and open public spaces. These facilities are suggested as cultural nodes in the UDG where all parties can be informed about sustainable living and the smart qualities of the settlement.

The smart city concept is an approach that integrates urban development with technology. In the UDG, smart city components are evaluated according to building and infrastructure, disaster management, and energy management. Smart buildings require information and communication technologies (ICT) in management and use. By using ICT, it is aimed to increase the efficiency of functions such as lighting and heating and cooling. Within this definition, smart sensors are suggested for urban and architectural design, especially for efficient health services and disaster management. These sensors are used for smart lighting, irrigation, HVAC (Heating, Ventilation, Air Conditioning) systems, data collection, and tracking. Real-time distribution of information provided through smart billboards are located in transportation nodes (see Fig.14). Within the scope of smart city applications, the building infrastructure is suggested to be suitable for automated energy management tools. Design
Figure 12. Section of the main arterial road. Source: (HT-TTM, 2018c) 
A Review of Urban Design Guidelines in Turkey and The PerformanceBased Approach for Sustainability

alternatives for lighting equipment are suggested in the UDG integrated with solar panels and motion sensors for supporting energy efficiency (see Fig. 15).

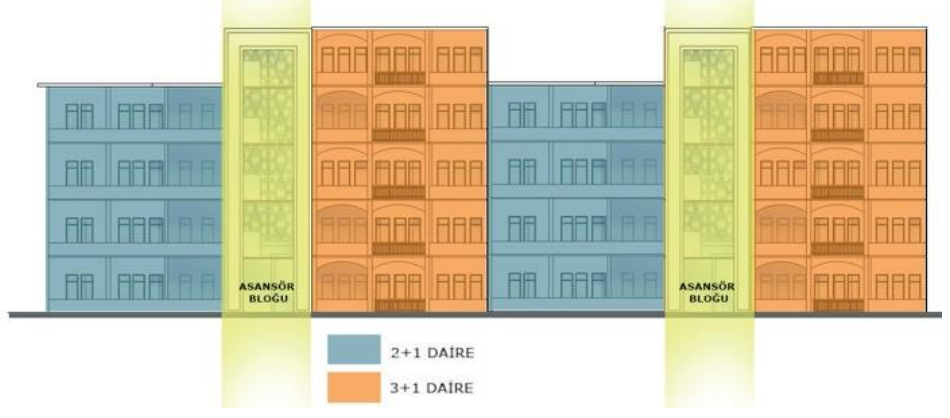

b)

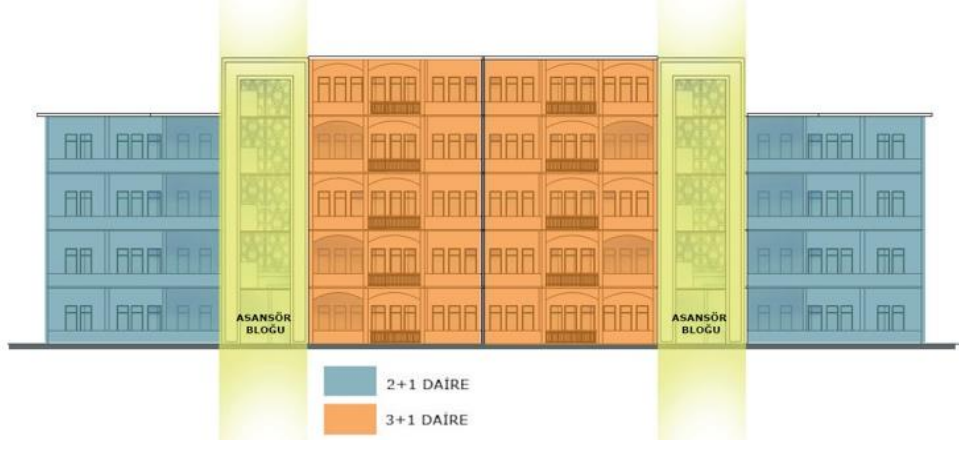

Figure 13. Modular design alternatives for cluster housing a) three (color blue) and four rooms (color orange) apartment types b) four rooms (color orange) and four rooms with patio (color green) apartment types. (HT-TTM, 2018c). For the translations see appx. 1.

d)

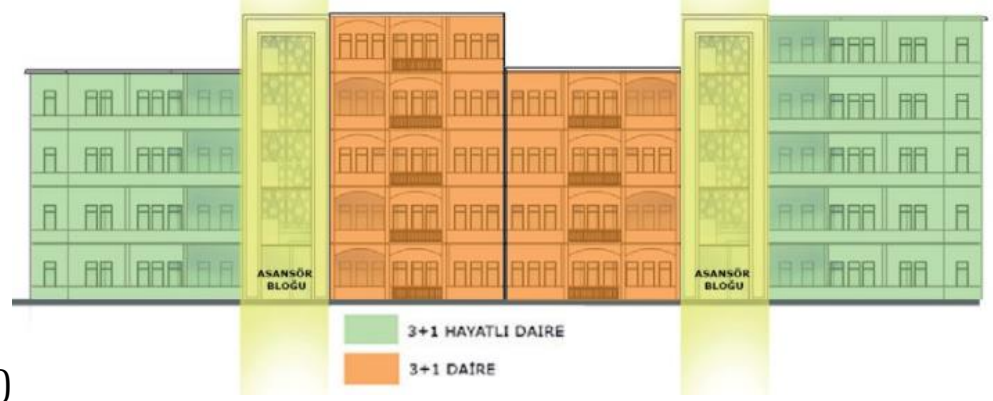

c)

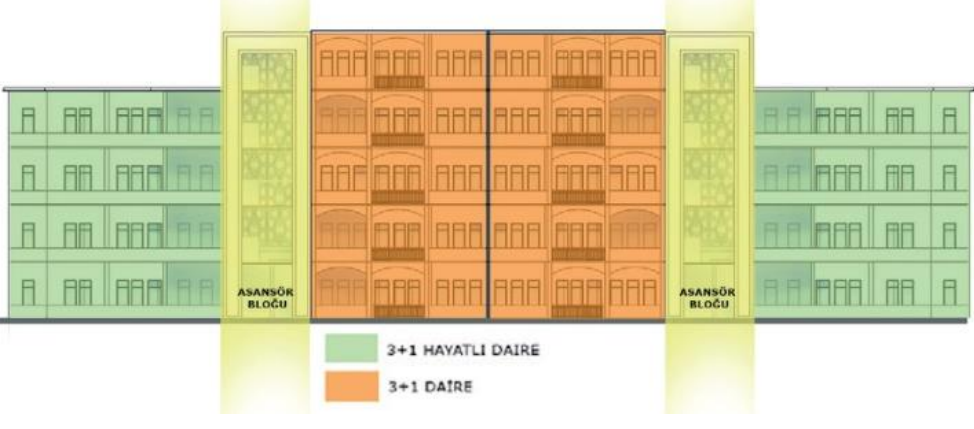


a)

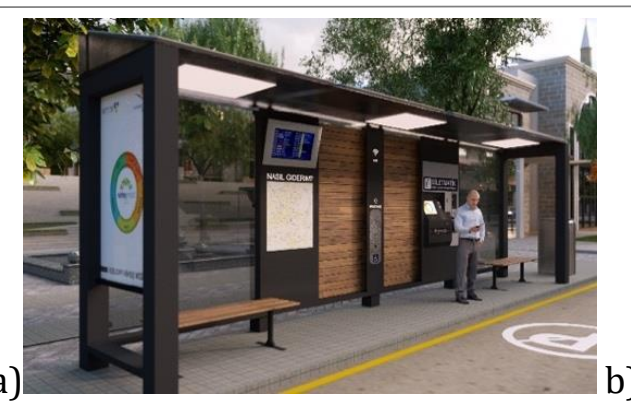

b)
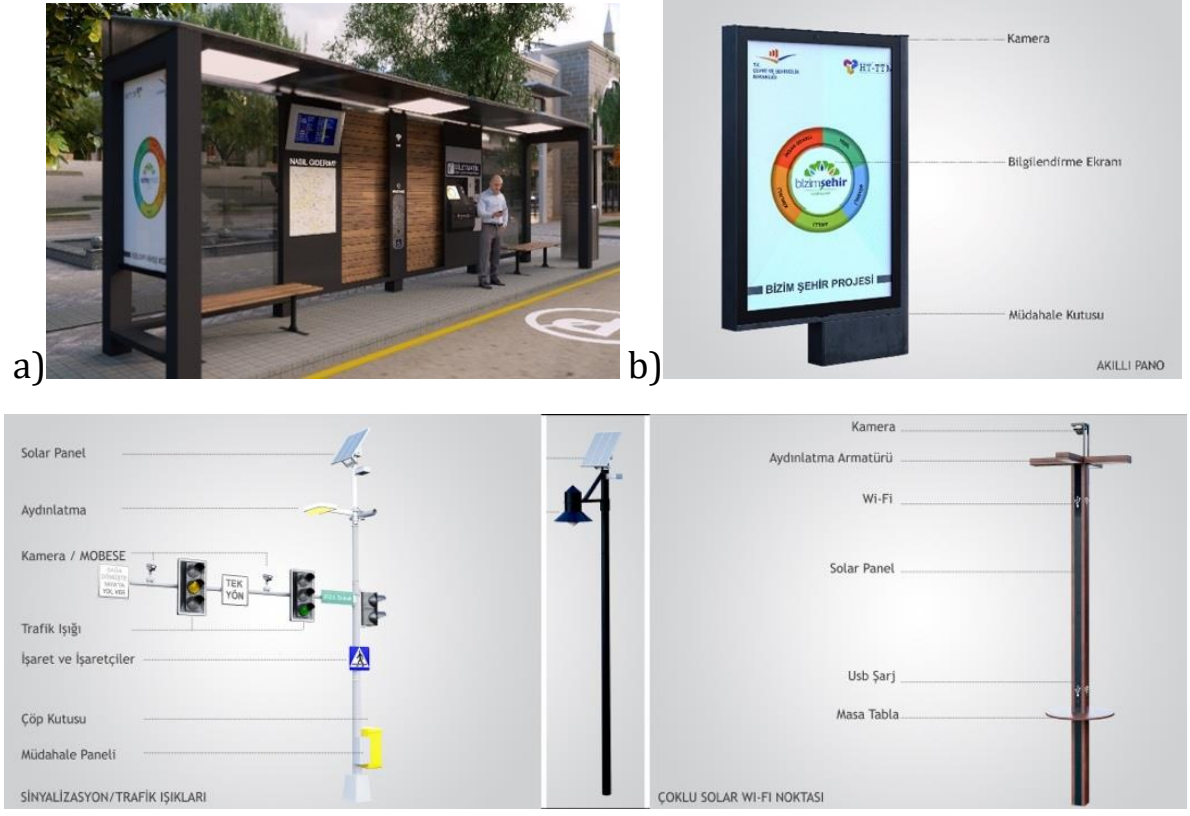

Green areas are considered as an 'open green system' that connects green belts with the inner city, open green areas, and green corridors. Landscape elements and pedestrian ways support climate control measurements (see Fig. 16). Design alternatives for these elements are created collaboratively by landscape architects, urban planners, and designers for the plans and the UDG. A list of local plants is given in the UDG for decreasing the maintenance costs in the green areas and increase sustainability throughout the settlement. Coherent with the local climate and universal design principles, the material selection for pavement is made to prevent slippery surfaces and tripping and allow rainwater to be absorbed by the soil. Green roofs and walls are suggested in the UDG to protect people from heat and cold (see Fig.16).

a)
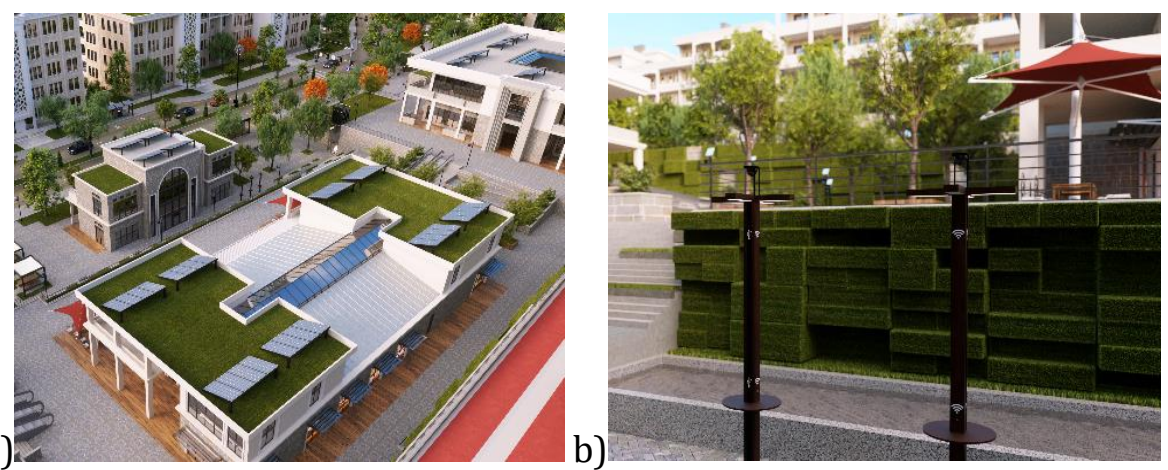

Great importance is given to the maximum benefit from daylight and control of the wind and sun. According to the dominant wind corridors and direction of the sun, buildings are oriented from northeast to southwest. Passive systems are enhanced by sunshades, openings, and sun collectors on façades. Efficient natural ventilation is suggested in the UDG at the neighborhood, urban block, and building levels instead of air conditioners (see Fig.17). Courtyards with water elements and vegetation are recommended as climate control elements in the design.
Figure 14. a) and b) Example design alternative for Public transportation stops and smart billboards (HT-TTM, 2018c). For the translations see appx. 1.

Figure 15. Example design alternatives for street signalization and traffic lights, light poles for pedestrian ways and open parking spaces, and multi solar wi-fi hotspots. (HTTTM, 2018c). For the translations see appx. 1.

Figure 16. Example design alternatives for a) green roofs b) green walls (HT-TTM, 2018c). 
A Review of Urban Design Guidelines in Turkey and The PerformanceBased Approach for Sustainability

This approach provided a connection with traditional Gaziantep houses. The existing water beds are protected by the master plan and regulations and their surroundings are designed as open green areas. A water treatment facility is located in the southwest region of the settlement in the master plan. With the UDG it is suggested to reuse the recycled water in irrigation of open green areas and gardens, and in toilet flush.

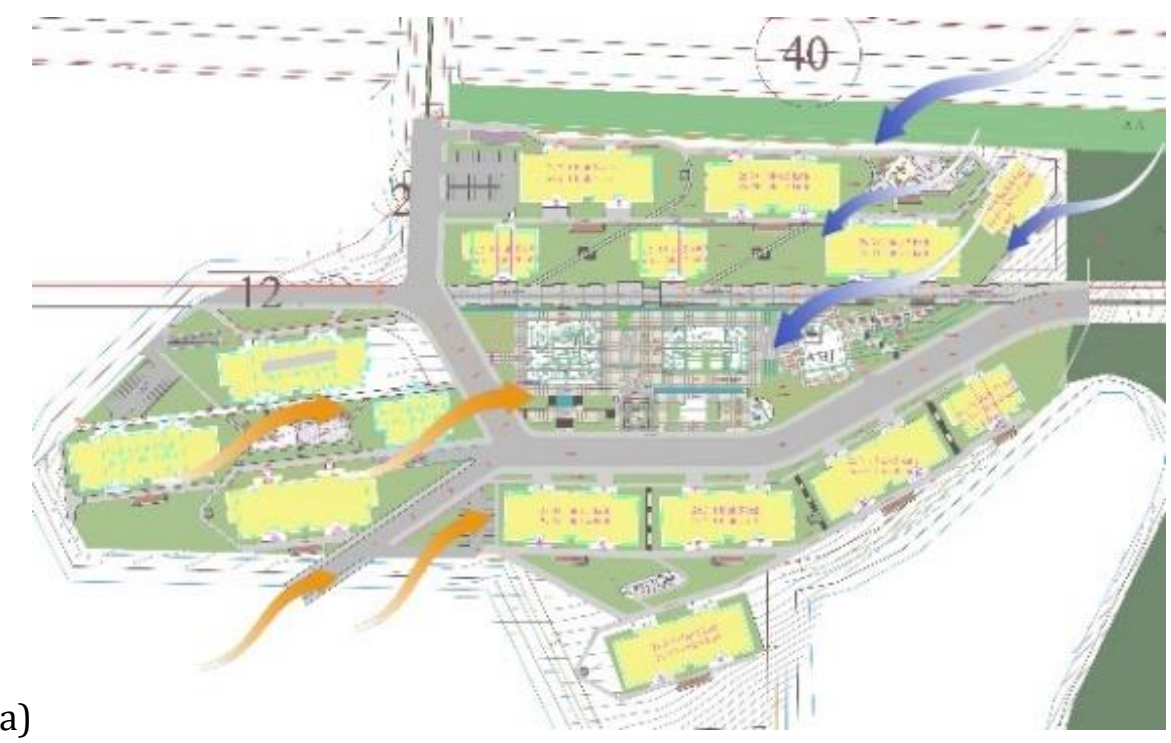

Figure 17. Summer and winter wind corridors at a) neighbourhood scale b) urban block scale c) building scale. (HT-TTM, 2018c).

b)

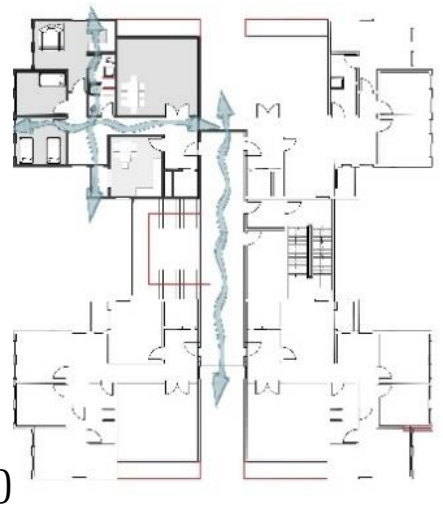

c)

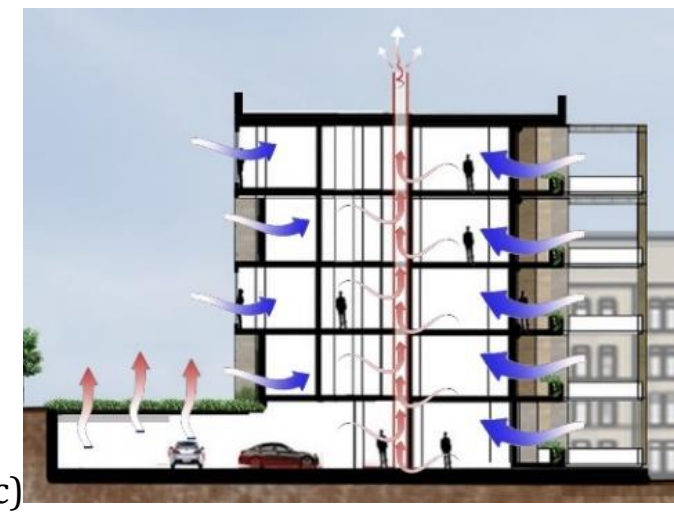

The safety of the settlement has been discussed for social and spatial measures in the UDG. According to the related measurements, lighting elements are located along the pedestrian and motorways according to the national standards. The design alternatives for the light poles are recommended to direct the light downward and to prevent light pollution and disturbance to the natural habitat. Earthquakes create an important risk for Turkish cities including Gaziantep. This condition requires an effective risk management strategy including effective spatial measurements. Hence, all spatial applications and construction activities should be according to the Building Earthquake Regulation and related disaster management regulations. Therefore, risk management measurements specific to the area were determined by a multidisciplinary team of earthquake engineers, geological engineers, and civil engineers for the UDG. 
The identity of the settlement was considered by each task force separately and integrated into the UDG based on these components at architectural and urban scales. The geographical character of the area is high in elevation and surrounded by steep slopes. Therefore, the existing valleys are suggested for protection with its biodiversity. In the regions where the slope is high, low density, low rise development is recommended for the protection of urban silhouette. Local materials such as Basalt are encouraged with the concern of material and product life cycle, local economy, and sustainable environment (see Fig. 18). Gaziantep is a part of the UNESCO Creative Cities Network with its unique gastronomy culture. One of the main pedestrian public areas is designed as Gastronomy Street to support the identity of the city.

a)
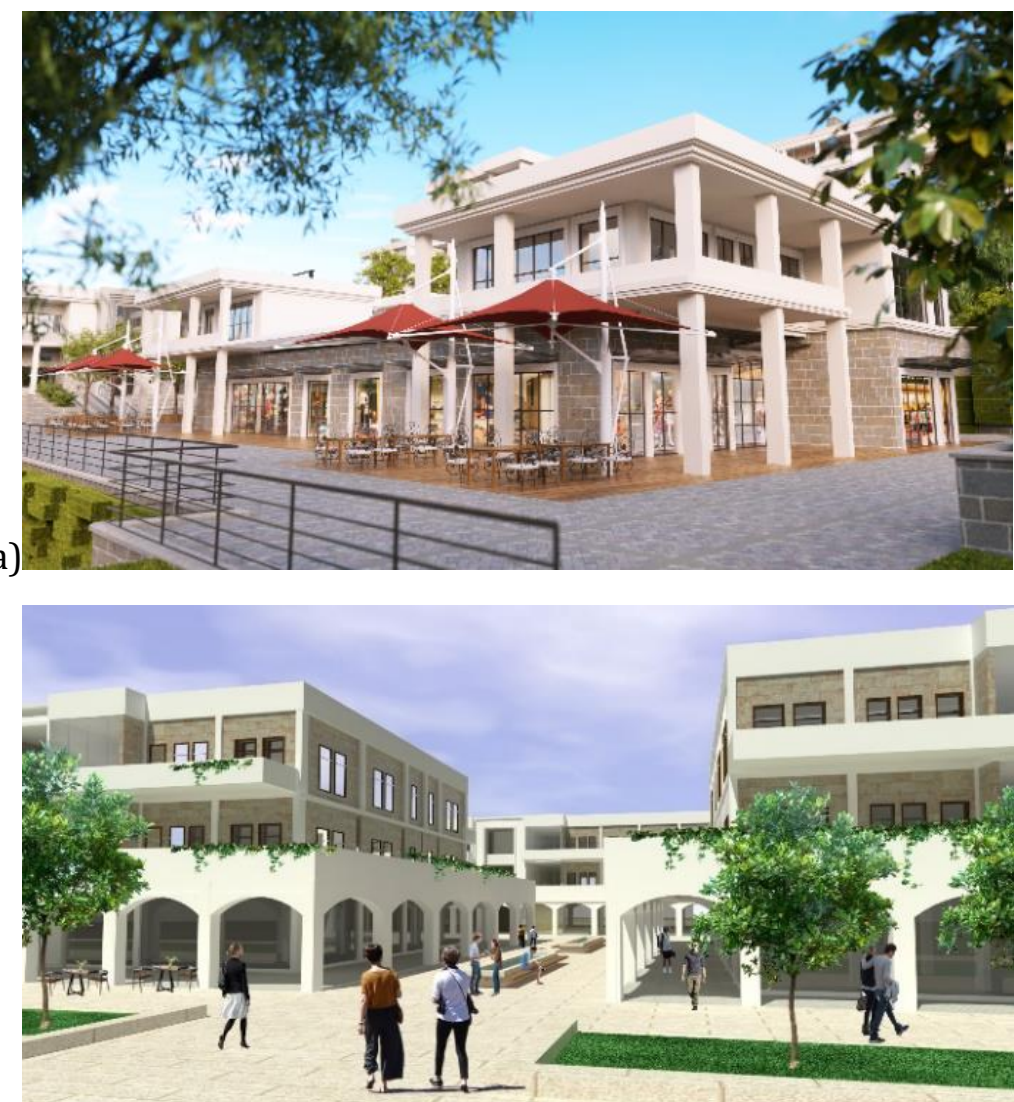

b)

Bizim Şehir Gaziantep performance-based UDG provides an extensive document for future applications at different scales from district to interior architecture. The overall project presents an important example of integrated urban planning and design processes by the interdisciplinary and inter-scale approach.

\section{RESULTS AND DISCUSSION}

In this section, three examples discussed are evaluated according to the sustainability criteria set. The criteria set is aggregated for this paper based on three urban sustainability frameworks that provide crossborder applicability, application scalability, and global geographic
Figure 18. a) and b) Examples from commercial buildings (HT-TTM, 2018c). 
representation based on flexible and globally applicable indicators (see Table 1). After the evaluation, İzmir Kemeraltı met 15\%, Rize advisory UDG 45\% and Bizimsehir Gaziantep performance-based UDG $81 \%$ of all criteria.

The evaluation of UDGs revealed that urban design quality and governance are the common ground for all UDG approaches (see Table 3, Fig. 19). Following the detailed architectural and regulation-based characteristics of the prescriptive UDGs, Izmir Kemeraltı UDGs could not receive any scores from the categories except these two. Rize advisory UDG encapsulated all categories in brief and provided a balanced distribution in principles (see Table 3, Fig. 19). Following the advisory approach, the UDG supported urban sustainability comprehensively but briefly. Thus, the aim of the UDG was not to provide detailed urban design principles. It aimed to present a clear roadmap for sustainable urban development with a broad perspective. Special importance is given in the UDG to urban design quality and environmental quality. Bizimşehir Gaziantep performance-based UDG received the highest score in all categories except 'green growth and innovation' (see Fig. 19). The UDG exceeded the other examples remarkably in providing environmental quality by integrating social, green, and smart components. The interdisciplinary, well-integrated, and contextual approach served sustainable solutions and inclusiveness.

Each UDG example provided a completely different framework except targeting increased design quality and process management. They were integrated into the urban planning process at different levels. The preparation processes of each UDG involved local authorities and academy. The degree of multidisciplinarity changed according to the aim of the UDG.

In this scope, Izmir Kemeraltı prescriptive UDG provided obligatory, rulebased content as part of the conservation plans. On the contrary, Rize advisory UDG presented ideas, examples, and general, non-obligatory principles that define a roadmap for detailed applications. Both UDGs were prepared mainly by urban planners. Different from the two UDG approaches, Bizimsehir Gaziantep performance-based UDG required a multidisciplinary team that could provide detailed principles, tools, and methods for sustainable, smart, human-centered, and green settlement. Each principle, tool, and method described in the UDG aims to increase the sustainability performance of the designated area. They provide alternative solutions to implement for each category targeting the stakeholders. Therefore, performance-based UDGs need to achieve multidisciplinarity that will bring knowledge, experiences, and capabilities to the process. 
Table 3. Comparison of UDG examples in a compatibility matrix according to sustainable urban development criteria

\begin{tabular}{|c|c|c|c|c|}
\hline Target & Criteria & $\begin{array}{l}\text { Kemeraltı } \\
\text { Prescriptive } \\
\text { UDG }\end{array}$ & $\begin{array}{l}\text { Rize Advisory } \\
\text { UDG }\end{array}$ & \begin{tabular}{|l} 
Bizimşehir \\
Gaziantep \\
Performance- \\
based UDG
\end{tabular} \\
\hline \multirow[t]{7}{*}{ Urban Planning } & $\begin{array}{l}\text { Strategies for preserving and adapting open spaces to } \\
\text { improve quality of life }\end{array}$ & & & \\
\hline & Minimizing urban sprawl & & & \\
\hline & Optimizing population density & & & \\
\hline & \begin{tabular}{|l|} 
Connections between green areas \\
\end{tabular} & & & \\
\hline & Promotion of green spaces & & & \\
\hline & \begin{tabular}{|l} 
Accessibility and integrity of land uses \\
\end{tabular} & & & \\
\hline & Brownfield redevelopment & & & \\
\hline \multirow[t]{13}{*}{ Urban Design Quality } & Diversity & & & \\
\hline & Well defined public spaces & & & \\
\hline & Public and semi-public hierarchy & & & \\
\hline & Façade street relations & & & \\
\hline & Human scale urban design and architecture & & & \\
\hline & Street art and furnitures & & & \\
\hline & \begin{tabular}{|l} 
Landscape and vegetation integrated to built environment \\
\end{tabular} & & & \\
\hline & Shop façades and signboards & & & \\
\hline & Flexibility & & & \\
\hline & Mixed-use environments & & & \\
\hline & Smart and technology relates-solutions & & & \\
\hline & Neighbourhood schools & & & \\
\hline & Local food production & & & \\
\hline \multirow[t]{5}{*}{ Character and Identity } & Protection of local heritage & & & \\
\hline & Communication infrustracture and citizen participation & & & \\
\hline & Neighborhood design & & & \\
\hline & \begin{tabular}{|l|l} 
Promotion of local materials in urban design and architecture \\
\end{tabular} & & & \\
\hline & Coherence with local geography & & & \\
\hline \multirow[t]{6}{*}{ Mobility } & Integration of the different modes of transport & & & \\
\hline & \begin{tabular}{|l|} 
Increased accessibility for disadvantageous groups \\
\end{tabular} & & & \\
\hline & Continious mobility data collection & & & \\
\hline & Prediction of the future demand & & & \\
\hline & Future performance measurements & & & \\
\hline & Pedestrian an non-motorized vehicle access & & & \\
\hline \multirow[t]{6}{*}{ Security } & Pedestrian security & & & \\
\hline & Efficient lighting & & & \\
\hline & Efficent separation of transportation modes & & & \\
\hline & Slow traffic & & & \\
\hline & Balance between day and night time & & & \\
\hline & Risk management and mitigation for natural disasters & & & \\
\hline \multirow{8}{*}{$\begin{array}{l}\text { Environmental Quality } \\
\text { Nature and Biodiversity }\end{array}$} & Built and natural environment compliance & & & \\
\hline & Measurable objectives related to biodiversity & & & \\
\hline & Strategical approach & & & \\
\hline & Wildlife corridors & & & \\
\hline & Green infrastructure & & & \\
\hline & Ecosystem services & & & \\
\hline & Nature based solutions (green roofs, water treatment etc.) & & & \\
\hline & Community engagement & & & \\
\hline \multirow[t]{3}{*}{ Air quality } & Monitoring & & & \\
\hline & Long and short term objectives for air quality & & & \\
\hline & Community engagement & & & \\
\hline \multirow[t]{11}{*}{ Water } & Monitoring for consumption and leaks & & & \\
\hline & Reducing drinking water consumption & & & \\
\hline & Adjusting urban parks and green to cope with less water & & & \\
\hline & Sustainable gardening & & & \\
\hline & Gray water recycling & & & \\
\hline & Rainwater collection and use & & & \\
\hline & \begin{tabular}{|l} 
Innovative measures \\
\end{tabular} & & & \\
\hline & Quality and protection of surface waters & & & \\
\hline & Flood protection management & & & \\
\hline & Water treatment & & & \\
\hline & Community engagement & & & \\
\hline \multirow[t]{6}{*}{ Climate Change } & Monitoring for GHGs & & & \\
\hline & \begin{tabular}{|l|} 
Publicly available information \\
\end{tabular} & & & \\
\hline & \begin{tabular}{|l|} 
Coherence with national strategies and plans \\
\end{tabular} & & & \\
\hline & HVAC measures to reduce $\mathrm{CO} 2$ & & & \\
\hline & Energy saving meaures & & & \\
\hline & Heat island reduction & & & \\
\hline \multirow[t]{4}{*}{ Noise } & Quality of acoustic environment & & & \\
\hline & Noise map & & & \\
\hline & \begin{tabular}{|l|} 
Publicly available information \\
\end{tabular} & & & \\
\hline & Noise protection in sensitive areas (schools, ho & & & \\
\hline
\end{tabular}


A Review of Urban Design Guidelines in Turkey and The PerformanceBased Approach for Sustainability

Table 3 cont

\begin{tabular}{|c|c|c|c|c|}
\hline Target & Criteria & $\begin{array}{l}\text { Kemeraltı } \\
\text { Prescriptive } \\
\text { UDG }\end{array}$ & $\begin{array}{l}\text { Rize Advisory } \\
\text { UDG }\end{array}$ & \begin{tabular}{|l|} 
Bizimşehir \\
Gaziantep \\
Performance- \\
based UDG
\end{tabular} \\
\hline \multirow[t]{4}{*}{ Energy } & Monitoring and data collection for energy consumption & & & \\
\hline & Projections & & & \\
\hline & Targets for energy efficiency & & & \\
\hline & Renewable energy sources & & & \\
\hline \multirow[t]{6}{*}{ Waste } & Monitoring and assessment for wastes & & & \\
\hline & Strategies for collection and treatment of waste & & & \\
\hline & Projections & & & \\
\hline & Waste recycling & & & \\
\hline & Waste separation & & & \\
\hline & Waste prevention programs & & & \\
\hline \multirow{7}{*}{$\begin{array}{l}\text { Green Growth and } \\
\text { Innovation }\end{array}$} & Adoption of environmentally friendly technologies & & & \\
\hline & Creative green industry & & & \\
\hline & Green skills and/or jobs & & & \\
\hline & Sustainable flow of resources & & & \\
\hline & Vital local economy, enhancement of local businesses & & & \\
\hline & Energy efficiency in buildings and urban development & & & \\
\hline & Affordable housing & & & \\
\hline \multirow[t]{6}{*}{ Governance } & Integrated vision and/or policy framework & & & \\
\hline & Links to other policy documents & & & \\
\hline & $\begin{array}{l}\text { Environmental vision reflected in different strategies and } \\
\text { action plans }\end{array}$ & & & \\
\hline & Citizen participation & & & \\
\hline & Coorperation with authorities and organizations & & & \\
\hline & Examplary practices and projects & & & \\
\hline
\end{tabular}

Figure 19. Comparison of the guidelines on the inclusion of sustainable urban design criteria.

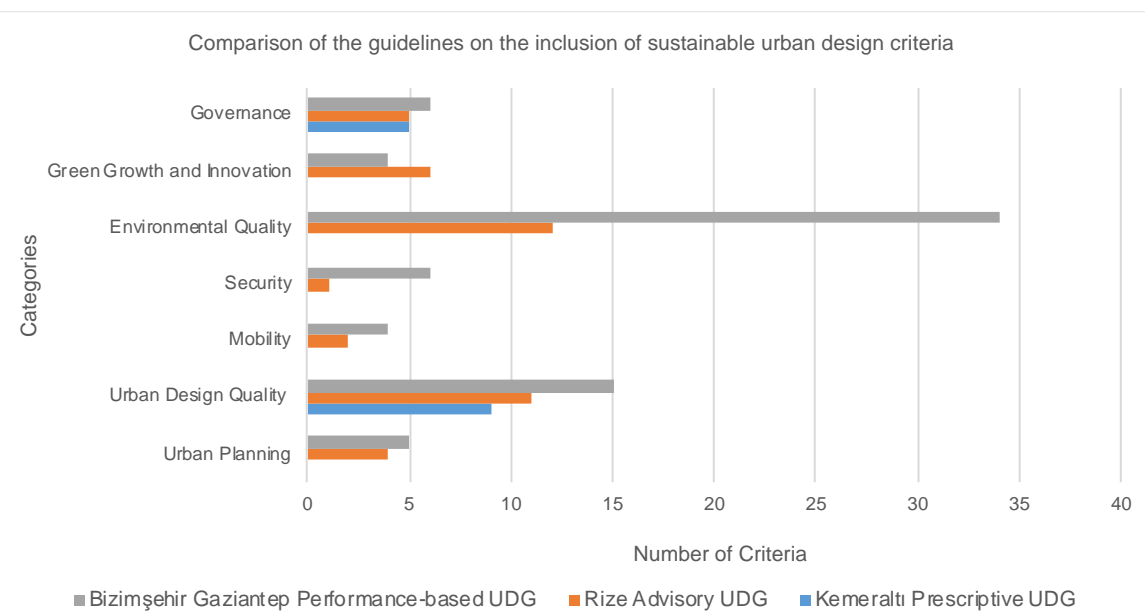

The comparison of three examples from each approach validates the increasing role of UDGs in Turkey in achieving urban sustainability from a broad perspective. The results revealed an understanding of how UDGs became a part of the urban planning process in Turkey. It is observed from the study that the role and extent of UDGs changed in time according to the increasing tendencies towards sustainable development. Their content became larger while sustainable urban development became a requirement. All three approaches are applicable at the district level (involving one or more neighbourhoods). On the other hand, decreased level of detail in principles enables applications at broader scales. For example, Izmir Kemeraltı prescriptive UDG focused on the commercial center of the city region, Rize advisory UDG covered the city and surroundings with less detail in the principles, and Bizimsehir Gaziantep performance-based UDG provided an intermediate detail in the 
principles and in terms of the scale (a group of mixed-use neighbourhoods). The evolution also increased the inclusiveness of various disciplines and enlarged the target groups.

\section{CONCLUSIONS AND RECOMMENDATIONS}

The integration of UDGs into the urban planning system is an evolving process in Turkey. The status quo of urban planning is insufficient to define the role of urban design and provide obligatory law enforcement towards the preparation of guidelines. On the other hand, according to the evaluation in this paper, the importance of UDGs is increasing following sustainable urban development trends. This relation between sustainability and UDGs was discussed in this paper through an extensive exploration and a structural evaluation of three examples. Therefore, the paper first introduced the existing literature, presented the current state of related applications and related processes in the context of Turkey. Based on the literature, the study focused on three common UDG approaches: prescriptive, advisory, and performance-based. Then it introduced, evaluated, and compared three successful examples from each UDG approach. The results provided a novel and contextual evaluation for the literature and a framework for similar contexts, especially in developing countries. Based on the results, the following bullet points are recommended for the selection and implementation of the appropriate UDG approach;

- Prescriptive UDGs reference directly to the implementation through detailed design alternatives at the architectural level. Therefore, these UDGs are more suitable to focus on the physical aspects of sustainability. These documents are usually provide binding and inflexible frameworks.

- Advisory UDGs should be considered when the aim is to provide general recommendations for the preparation of detailed UDGs and urban design projects specific to the region. These UDGs are the only types that are suitable for urban scale and above. Therefore, they provide a useful tool to define essential principles of urban sustainability at larger scales.

- Performance-based UDGs provide the most comprehensive framework in implementing sustainable urban development. They can be applied at various scales from the urban block, urban axis, neighbourhood, or urban region. These documents can be binding or non-binding according to the aim. Therefore, their applicability to different contexts is higher than the other two approaches. However, performance-based UDGs require multidisciplinary work and a high level of integration to the development processes (including urban planning, architectural design, and urban management).

In conclusion, UDGs should be coherent with urban plans, laws, acts, and regulations. Therefore, the content and the extent of a UDG, the diversity in the team, and the degree of integration to the urban planning process 
A Review of Urban Design Guidelines in Turkey and The PerformanceBased Approach for Sustainability

should be defined according to the vision in the regional context and the result aimed to be achieved with the UDG.

\section{ACKNOWLEDGEMENTS/NOTES}

The authors of this paper worked for the Bizim Şehir Gaziantep Project as members of urban planning and urban design teams and they were funded by Republic of Turkey, The Ministry of Environment and Urbanisation during the project in 2018.

\section{CONFLICT OF INTEREST}

No conflict of interest was declared by the authors.

\section{FINANCIAL DISCLOSURE}

The authors declared that this study has received no financial support.

\section{ETHICS COMMITTEE APPROVAL}

Ethics committee approval was not required for this article.

\section{LEGAL PUBLIC/PRIVATE PERMISSIONS}

No survey and in-depth interviews, that require legal permissions, were conducted during this research.

\section{REFERENCES}

CNU, NRDC, \& USGBC. (2011). LEED 2009 for Neighborhood Development. USGBC. www.usgbc.org

Dogan, U. (2020). Assessing the Urban Design Quality of Turkish Cities. In A. Almusaed, A. Almssad, \& L. Truong-Hong (Eds.), Sustainable Cities and Society (Vol. 56). IntechOpen. https://doi.org/10.5772/intechopen.89779

Dokuz Eylül University Department of City and Regional Planning. (2002). Kemeralti 1. Etap Kentsel Tasarım Rehberi.

Dokuz Eylül University Department of City and Regional Planning. (2009). Kemeralti 2.Etap 1. Bölge Kentsel Tasarım Rehberi.

European Commission. (2018). In-depth-report: Indicators for Sustainable Cities (Issue 12). https://doi.org/10.2779/121865

European Commission. (2020). European Commission Green City Tool. https://webgate.ec.europa.eu/greencitytool/home/

Gürler, E. (2018). The Performance of Relationship Between Instrument and Mechanism: The Hidden Value of Urban Design Guidelines for Sustainable Urban Development. In N. Charalambous, N. Z. Cömert, \& Ş. Hoşkara (Eds.), 1st Regional Conference: Cyprus Network of Urban Morphology CyNUM 2018 Proceedings (Vol. 1, Issue 1, pp. 93-108). 
Hakim, B. S. (2008). Mediterranean urban and building codes: Origins, content, impact, and lessons. Urban Design International, 13(1), 21-40. https://doi.org/10.1057/udi.2008.4

Hall, Arthur Crawshay (1996). Design Control: Towards a New Approach. Oxford: Butterworth Architecture.

HT-TTM. (2018a). Bizim Şehir Gaziantep İli Pilot Bölge Çalışması 1/1000 Uygulama İmar Planı Açıklama Raporu.

HT-TTM. (2018b). Bizim Şehir Gaziantep İli Pilot Bölge Çalışması 1/5000 Ölçekli Nazım Planı Açıklama Raporu.

HT-TTM. (2018c). Bizim Şehir Gaziantep İli Pilot Bölge Çalışması Kentsel Tasarım Rehberi (S. Özdal Oktay (ed.)). Republic of Turkey Ministry of Environment and Urbanisation.

Kenttam. (2016a). Kentsel Tasarım Rehberleri Vol.I Araştırma ve Tanımlama. Republic of Turkey Ministry of Environment and Urbanisation.

https://webdosya.csb.gov.tr/db/mpgm/editordosya/file/Kentsel

Karaman, A. (1999). Bir Disiplin ve Meslek Olarak Kentsel Tasarimin Yeni Konumu ve İçeriği. 1st National Urban Design Congress, 234-239, İstanbul: Mimar Sinan Fine Arts University,Faculty of Architecture, Department of City and Regional Planning

Kenttam. (2016b). Kentsel Tasarım Rehberleri Vol.II İçerik. Republic of Turkey Ministry of Environment and Urbanisation. https://webdosya.csb.gov.tr/db/mpgm/editordosya/file/Kentsel

Kenttam. (2016c). Kentsel Tasarım Rehberleri Vol.III Mevzuat. Republic of Turkey Ministry of Environment and Urbanisation. https://webdosya.csb.gov.tr/db/mpgm/editordosya/file/Kentsel

Kenttam. (2017). Kentsel Mekansal Standartların Geliştirilmesi (1st ed., Issue 1). ReRepublic of Turkey Ministry of Environment and Urbanisation.

Lang, J. (1996). Implementing urban design in America: Project types and methodological implications. Journal of Urban Design, 1(1), 7-22. https://doi.org/10.1080/13574809608724368

Mega, V., \& Pedersen, J. (1998). Urban Sustainability Indicators. European Foundation for the Improvement of Living and Working Conditions. https://www.eurofound.europa.eu/sites/default/files/ef_files/pubdocs /1998/07/en/1/ef9807en.pdf

MSGSÜ. (2017). Rize Kensel Tasarım Vizyonu. Rize Municipality. http://www.rize.bel.tr/dosyalar/Rize2053/Rize-2053-Kentsel-

Tasarim-Vizyonu.pdf 
A Review of Urban Design Guidelines in Turkey and The PerformanceBased Approach for Sustainability

Punter, J. (1996). Urban Design Theory in Planning Practice: The British Perspective. Built Environment (1978-), 22(4), 263-277. http://www.jstor.org/stable/23288422

Punter, J. (1999). Seattle. In Design Guidelines in American Cities (pp. 3165). Liverpool University Press. http://www.jstor.org/stable/j.ctt1gn6bsv.8

Republic of Turkey Ministry of Environment and Urbanisation. (2010a). KENTGES Bütünleşik Kentsel Gelişme Stratejisi ve Eylem Planı 20102023. Republic of Turkey Ministry of Environment and Urbanisation. http://www.kentges.gov.tr/_dosyalar/kentges_tr.pdf

Republic of Turkey Ministry of Environment and Urbanisation. (2010b). Urban development strategy (2010 - 2023). https://webdosya.csb.gov.tr/db/kentges/icerikler/kentges-en20191223090807.pdf

Symes, M., \& Pauwels, S. (1999). The diffusion of innovations in urban design: The case of sustainability in the Hulme development guide. Journal of Urban Design, 4(1), 97-117. https://doi.org/10.1080/13574809908724440

Shirvani, H. (1990). Beyond Public Architecture: Strategies for Design Evaluations. New York: Van Nostrand Reinhold.

Yalçıner Ercoşkun, Ö., \& Karaaslan, S. (2011). Guidelines for Ecological and Technological Built Environment: A Case Study on Güdül-Ankara, Turkey. Gazi University Journal of Science, 24(3), 617-636. 


\section{APPENDIX}

Appendix 1 Index of Turkish descriptions in the images used in the paper and their English translations

\begin{tabular}{|c|c|c|}
\hline No. & $\begin{array}{l}\text { Turkish words and descriptions used in the images } \\
\text { (Ascending alphabetic order) }\end{array}$ & English translation \\
\hline 1 & Açık otopark & Open parking space \\
\hline 2 & Ada & Urban block \\
\hline 3 & Ahşap kap. & Timber coating \\
\hline 4 & Ahşap köşe silmesi & Timber corner molding \\
\hline 5 & Akıllı pano & Smart board \\
\hline 6 & Asansör bloğu & Elevator block \\
\hline 7 & Artvin & A city in the Black Sea Region of Turkey \\
\hline 8 & Avlu tipleri & Courtyard typologies \\
\hline 9 & Aydınlatma & Lighting \\
\hline 10 & Aydınlatma armatürü & Light fixture \\
\hline 11 & Bahce & Garden \\
\hline 12 & Belediye & Municipality \\
\hline 13 & Bilgilendirme ekranı & Information monitor \\
\hline 14 & Bitişik yapı & Contiguous building \\
\hline 15 & Cam & Glass \\
\hline 16 & Cami & Mosque \\
\hline 17 & Çarşı & Bazaar \\
\hline 18 & Çaykur & A state owned tea producing company \\
\hline 19 & Cephe & Facade \\
\hline 20 & Cephe çoğun sıvalı, bazen ahşap kaplamalıdır & Facade are generally coated, sometimes wood sided \\
\hline 21 & Çeşitli tipteki armatürler akraba tasarımlarda olmalıdır & Various types of fixtures should be related in design \\
\hline 22 & Çiçeklik yan görünüş & Flower pot side view \\
\hline 23 & Çiftli uzun direk tipi & Double long pole type \\
\hline 24 & $\begin{array}{l}\text { Çizimdeki örnek kare, altıgen veya sekizgen kesit } \\
\text { veren şekillerde olabilir }\end{array}$ & $\begin{array}{l}\text { The square example in the figure can be in shape that } \\
\text { has hexagon or octagon section }\end{array}$ \\
\hline 25 & Çöp kutusu & Garbage bin \\
\hline 26 & Demir kapı & Iron door \\
\hline 27 & Dere & Stream \\
\hline 28 & Dış söve & Outer door frame \\
\hline 29 & Döküm demir & Cast iron \\
\hline 30 & Dükkan & Shop/Store \\
\hline 31 & Dükkana dönüşmüş konut & $\begin{array}{l}\text { Commercial building converted from a residential } \\
\text { building }\end{array}$ \\
\hline 32 & Duvar & Wall \\
\hline 33 & Duvarda ankastre & Wall embedded \\
\hline 34 & Eksen & Axis \\
\hline
\end{tabular}

\section{Resume}

Simge Özdal Oktay is an urban designer who pursued her Master and Ph.D. studies on participatory methods in urban design and sustainabile urban development. Currently, she is a Post-Doctoral Researcher at the University of Münster, Institute for Geoinformation and continues to explore innovative solutions in communitybased, sustainable urban development.

Özge Yalçıner Ercoşkun is a professor in the City and Regional Planning Department, Gazi University, Ankara, Turkey. She graduated from the City and Regional Planning Department of the Istanbul Technical University in 1998. She completed her master studies in the Geodetic and Geographic Information Technologies Department at the METU in 2002. She received her Ph.D. from the City and Regional Planning Department, Gazi University in 2007. Her works focus on 
A Review of Urban Design Guidelines in Turkey and The PerformanceBased Approach for Sustainability

sustainable urban design and ecological and smart urban planning, resilient cities, sustainable transportation and geographic information technologies. 